\title{
Application of Bacteriophages to Limit Campylobacter in Poultry Production
}

\author{
Elena G. Olson ${ }^{1}$, Andrew C. Micciche'2, Michael J. Rothrock Jr. ${ }^{3}$, Yichao Yang ${ }^{4}$ and \\ Steven C. Ricke ${ }^{1 *}$ \\ ${ }^{1}$ Meat Science and Animal Biologics Discovery Program, Department of Animal and Dairy Sciences, University \\ of Wisconsin-Madison, Madison, WI, United States, ${ }^{2}$ Center for Food Safety, Department of Food Science, University \\ of Arkansas, Fayetteville, AR, United States, ${ }^{3}$ Agricultural Research Service, United States Department of Agriculture, \\ Athens, GA, United States, ${ }^{4}$ Department of Poultry Science, University of Arkansas, Fayetteville, AR, United States
}

Campylobacter is a major foodborne pathogen with over a million United States cases a year and is typically acquired through the consumption of poultry products. The common occurrence of Campylobacter as a member of the poultry gastrointestinal tract microbial community remains a challenge for optimizing intervention strategies. Simultaneously, increasing demand for antibiotic-free products has led to the development of several alternative control measures both at the farm and in processing operations. Bacteriophages administered to reduce foodborne pathogens are one of the alternatives that have received renewed interest. Campylobacter phages have been isolated from both conventionally and organically raised poultry. Isolated and cultivated Campylobacter bacteriophages have been used as an intervention in live birds to target colonized Campylobacter in the gastrointestinal tract. Application of Campylobacter phages to poultry carcasses has also been explored as a strategy to reduce Campylobacter levels during poultry processing. This review will focus on the biology and ecology of Campylobacter bacteriophages in poultry production followed by discussion on current and potential applications as an intervention strategy to reduce Campylobacter occurrence in poultry production.

Keywords: Campylobacter, poultry, bacteriophage, post-harvest, pre-harvest

\section{INTRODUCTION}

According to the World Health Organization, Campylobacter is a leading cause of the diarrheal disease (World Health Organization [WHO], 2018). The genus Campylobacter is comprised of over 20 species. Strains of Campylobacter jejuni and Campylobacter coli are generally considered some of the more significant concerns among foodborne pathogens for human health (Korczak et al., 2006; Havelaar et al., 2012; World Health Organization [WHO], 2018; Centers for Disease Control and Prevention [CDC] (2019)). European Food Safety Authority (EFSA) has declared campylobacteriosis as being one of the most commonly reported foodborne diseases since 2005, with over 200,000 cases per year, representing 70\% of the human zoonoses in the E.U. (European Food Safety Authority [EFSA], 2020). In one study in the United Kingdom (U.K.), it was reported that $50-80 \%$ of poultry harbored Campylobacter in their intestinal tract (Connerton et al., 2011; 
European Food Safety Authority [EFSA], 2011, 2020). These numbers are similar to those found in poultry produced in the United States (U.S.) (Hanning et al., 2010; Chapman et al., 2016).

With populations in the bird cecum in some instances exceeding seven $\log _{10}$ colony-forming units (CFU) per gram of cecal content, this genus appears to be specifically well suited to reside within the poultry gastrointestinal tract (GIT) (Rudi et al., 2004; Connerton et al., 2011; Indikova et al., 2015). Consequently, Campylobacter can be released from the poultry GIT as birds are being processed, potentially contaminating poultry processing plant equipment and the finished product (Elvers et al., 2011; García-Sánchez et al., 2017). Furthermore, Campylobacter contamination in the poultry processing plant can remain a persistent problem. Given the poultry GIT establishment and subsequent likelihood of contamination in the poultry plant, poultry meat products are considered a significant source of potential infection for human campylobacteriosis (Umaraw et al., 2017). Pre-and postharvest interventions have been utilized and proposed over the years to reduce Campylobacter populations in poultry (Umaraw et al., 2017; Kim et al., 2019; Deng et al., 2020). One intervention that has received more interest as a potential intervention for Campylobacter is the administration of Campylobacter phages. This review aims to focus specifically on the ecology of Campylobacter phages, their mechanisms of bacterial host infection, host resistance, and their applications in both pre-and postharvest as intervention strategies toward reducing Campylobacter in poultry production. Due to the lytic characteristic that phages possess, multi-pronged interventions that include combination of phages with non-phage technologies, such as acids and endolysins, throughout poultry processing steps may result in efficient reduction of Campylobacter under commercial conditions.

\section{CAMPYLOBACTER PHAGE - CLASSIFICATION AND MECHANISMS OF HOST INFECTION}

The first Campylobacter phages were likely isolated in 1960 in cattle and pigs from then identified Vibrio coli and Vibrio fetus, now known as C. coli and C. fetus (Fletcher and Bertschinger, 1964; Fletcher, 1968). A few of the over 170 known phages infect C. jejuni, and most of them are specific to the bacterial host (Ushanov et al., 2020). Almost all currently isolated phages that infect Campylobacter are from the family Myoviridae and morphologically distinguished as Bradley's morphotype A1 with a contractile tail (Gencay et al., 2018; Jäckel et al., 2019; Ushanov et al., 2020; Table 1). Some Campylobacter bacteriophages are from the family of Siphoviridae and possess Bradley's morphotype B1 with a non-contractile tail (Ushanov et al., 2020). Furthermore, lytic phages that target Campylobacter are typically assembled into three groupings (I, II, III) based on genome size (Jäckel et al., 2019; Ushanov et al., 2020). Group I lytic phages are $320 \mathrm{~kb}$ in genome size and considered unstable, with only two isolates being identified (Frost et al., 1999; Connerton et al., 2018). Although both group II and III have been demonstrated to be useful for phage therapy, most isolated Campylobacter phages belong to group III (Sails et al., 1998; El-Shibiny et al., 2009; Carvalho et al., 2010). Group II phages with an average genome size of 162,601 base pairs, and Group III phages (133, 166 base pairs) comprise approximately half the group I phages' genomic size (Jäckel et al., 2019). Group II phages have a protein head diameter of 83 to $99 \mathrm{~nm}$ (Carvalho et al., 2010; Jäckel et al., 2019). Group III phages have a head diameter of 100-130 nm, whereas Group I phages possess much larger head proportions (Jäckel et al., 2019). Based on whole genome sequencing and protein analysis, groups II and III bacteriophages can be further combined into the Eucampyvirinae sub-family (Ushanov et al., 2020). Zampara et al. (2017) further grouped C. jejuni phages based on receptor dependency, namely, group III phages use CPS receptors, and group II phages contact the host via flagella.

Several phage receptors in Gram-negative bacteria have been recognized, which consist of bacterial surface components such as lipopolysaccharides (LPS), CPS, flagella, outer membrane proteins (Omps), and porins (Rakhuba et al., 2010). For instance, the T-even phages, such as Escherichia coli T4 phage, which is the model of the Myoviridae phages having contractile tail structure, are among the best-characterized phages (Sørensen et al., 2011). T-even phages recognize and bind to a variety of Omps or specific structures within LPS in E. coli. Bacterial receptors in other Gram-negative bacteria that are recognized by phages consist of structures within LPS such as $\mathrm{O}$ antigens and carbohydrate moieties (Kiljunen et al., 2005; Petty et al., 2007). The $\mathrm{O}$ antigens are central features of E. coli and C. jejuni cells surface and represent essential factors of infection and disease associated with humans (Mills et al., 1992; Stenutz et al., 2006). Application of phages that bind $\mathrm{O}$ antigens may help reduce the virulence of pathogens such as Campylobacter within human GIT and thus may be beneficial in postharvest applications for poultry meat intended for retail destinations such as ready to eat meats.

\section{CAMPYLOBACTER PHAGE-ECOLOGY}

Campylobacter phages have been isolated wherever their hosts exist, such as the feces of sheep, cows, pigs (Hansen et al., 2007; Rizzo et al., 2015; An et al., 2018); slaughterhouse run-offs, sewage, manure, excreta of chickens and their meat (Grajewski et al., 1985; Salama et al., 1989; Sails et al., 1998; Atterbury et al., 2005; Connerton et al., 2004, 2011; El-Shibiny et al., 2005; Loc Carrillo et al., 2007; Tsuei et al., 2007). Reports on the isolation of bacteriophages from poultry are considerably variable. For example, out of 205 broiler ceca, approximately $20 \%$ were positive for Campylobacter bacteriophages in the U.K., and a similar result was observed with broilers in South Korea (Atterbury et al., 2005; Hwang et al., 2009). However, in a Denmark study, the Campylobacter bacteriophages' isolation rate from conventionally raised broiler intestines was only 3\% (Hansen et al., 2007). In contrast to these low rates of isolation, Owens et al. (2013) reported that $100 \%$ of the fecal samples from free-range broilers and egg layers tested positive for C. jejuni phages. El-Shibiny et al. (2005) isolated 51\% Campylobacter phages from the Campylobacter-positive organic chickens from a U.K. flock. This increase makes sense because free-range birds 
TABLE 1 | Campylobacter phages taxonomy and description.

\begin{tabular}{|c|c|c|c|c|c|c|c|c|c|c|}
\hline $\begin{array}{l}\text { Order } \\
\text { (Harper } \\
\text { et al., } \\
\text { 2014) }\end{array}$ & $\begin{array}{l}\text { Family (Sharp, } \\
\text { 2001; Gencay } \\
\text { et al., 2018; } \\
\text { Huang et al., } \\
\text { 2020; } \\
\text { Ushanov } \\
\text { et al., 2020) }\end{array}$ & $\begin{array}{l}\text { Nucleic } \\
\text { acid type } \\
\text { and phage } \\
\text { example } \\
\text { (Harada } \\
\text { et al., } \\
2018 \text { ) }\end{array}$ & $\begin{array}{l}\text { Morphotype } \\
\text { (Sails } \\
\text { et al., } \\
1998 \text { ) }\end{array}$ & $\begin{array}{l}\text { Grouping } \\
\text { not based } \\
\text { on } \\
\text { genome } \\
\text { analysis } \\
\text { (Jäckel } \\
\text { et al., } \\
\text { 2019) }\end{array}$ & $\begin{array}{l}\text { Genome } \\
\text { size } \\
\text { (Huang } \\
\text { et al., } \\
\text { 2020) }\end{array}$ & $\begin{array}{l}\text { Applicability } \\
\text { (Carvalho et al., } \\
\text { 2010; Connerton } \\
\text { et al., 2018; } \\
\text { Huang et al., } \\
\text { 2020) }\end{array}$ & $\begin{array}{l}\text { Genera based on } \\
\text { genome } \\
\text { sequencing } \\
\text { (Javed et al., } \\
\text { 2014) }\end{array}$ & $\begin{array}{l}\text { Phages } \\
\text { (Javed et al., } \\
\text { 2014; Jäckel } \\
\text { et al., 2019; } \\
\text { Huang et al., } \\
\text { 2020) }\end{array}$ & $\begin{array}{l}\text { Phage resistance } \\
\text { development } \\
\text { (Janez and } \\
\text { Loc-Carillo, 2013) }\end{array}$ & $\begin{array}{l}\text { Host } \\
\text { range } \\
\text { (Jäckel } \\
\text { et al., } \\
2019 ; \\
\text { Huang } \\
\text { et al., } \\
2020 \text { ) }\end{array}$ \\
\hline \multirow[t]{5}{*}{ Caudovirales } & Myoviridae & $\begin{array}{l}\text { Linear } \\
\text { dsDNA } \\
\text { (T4) }\end{array}$ & $\begin{array}{l}\text { Morphotype } \\
\text { A1 with } \\
\text { contractile } \\
\text { tail }\end{array}$ & Group I & $\sim 320 \mathrm{~kb}$ & Unstable & & & Motility defect & \\
\hline & & & & Group II & $\begin{array}{l}\text { Average } \\
\sim 162,601\end{array}$ & $\begin{array}{l}\text { Stable for phage } \\
\text { therapy }\end{array}$ & CP220virus & $\begin{array}{l}\text { CP21, CP220, } \\
\text { Cpt10, } \\
\text { vB-Ccom-IBB-35 }\end{array}$ & Motility defect & $\begin{array}{l}\text { C. jejuni } \\
\text { and C. coli }\end{array}$ \\
\hline & & & & Group III & $\begin{array}{l}\text { Average } \\
\sim 133,166\end{array}$ & $\begin{array}{l}\text { Stable for phage } \\
\text { therapy }\end{array}$ & CP8virus & $\begin{array}{l}\text { CP81, CPX, } \\
\text { NCTC12673, } \\
\text { Cp30A, PC14, } \\
\text { PC5, } \\
\text { vB_CjeM_Los1, } \\
\text { CP8 }\end{array}$ & CPS structure & C. jejuni \\
\hline & Siphoviridae & $\begin{array}{l}\text { Linear } \\
\text { dsDNA } \\
\text { (Lambda) }\end{array}$ & $\begin{array}{l}\text { Morphotype } \\
\text { B1 with } \\
\text { non- } \\
\text { contractile } \\
\text { tail }\end{array}$ & & $15-17$ kb & $\begin{array}{l}\text { Stable for phage } \\
\text { therapy }\end{array}$ & & CAM-P21 & & C. coli \\
\hline & Podoviridae & & & & & & & & & \\
\hline
\end{tabular}


potentially encounter a wider variety of Campylobacter species and their phages because they are exposed to a broader range of environmental surroundings (Hald et al., 2001; Atterbury et al., 2003 b). In general, the likelihood of phage recovery potentially increases with the presence of a susceptible host; therefore, birds with higher colonization rates of Campylobacter are more likely to be sources of phages (Atterbury et al., 2003b).

Campylobacter colonization in poultry can vary considerably and this can impact the contamination levels throughout the poultry production chain. In a study by Rudi et al. (2004), the concentration of $C$. jejuni in poultry ceca exhibited a 1,000fold difference in range throughout a number of flocks. If the strain colonizing one community has an infectious dose that is $0.1 \%$ of the strain colonizing another flock, then these two strains would be considered relatively equivalent in their likelihood to cause illness through food contamination (from a human infectivity standpoint) (Rudi et al., 2004). Since up to $76 \%$ of chickens slaughtered can be Campylobacter positive, contamination management continues to be an important challenge to poultry production (Humphrey et al., 1993). In addition, with cross-contamination occurring in the slaughterhouse, Campylobacter and phages discovered on a single chicken carcass may have originated from more than one source (Atterbury et al., 2003b). Although, tracking of phages might be difficult throughout poultry processing due to cross-contamination effects, the capability of phages to persist throughout poultry processing demonstrated by Atterbury et al. (2003a) is an essential characteristic of their future use in the biocontrol of Campylobacter in poultry processing. The phages isolated in this study exhibited a broad range of recovery rates from chicken skin stored at $4^{\circ} \mathrm{C}$ (Atterbury et al., 2003a). Furthermore, the stated detection limit for phage recovery of $2 \times 10^{3} \mathrm{PFU} / 10 \mathrm{~cm}^{2}$ of chicken skin suggests that there are at least that many phages persisting throughout the commercial poultry processing and packaging operation.

\section{ISOLATION, PROPAGATION, CONCENTRATION, AND PURIFICATION OF CAMPYLOBACTER PHAGES}

Isolation strategies may impact both the extent and the type of Campylobacter phages detected in different ecosystems. The outline and main concepts for the following procedures are briefly described in Figure 1. The first step for isolation is collecting the samples. Samples should not be frozen or vortexed as these treatments may significantly reduce the plaque-forming ability (Atterbury et al., 2003a; Jäckel et al., 2017). Although Atterbury et al. (2003a) were able to isolate Campylobacter phages from over $10 \%$ of chilled chicken thighs by plaque assay, Jäckel et al. (2017) reported reduced lytic activity of phages from samples that were previously frozen.

Even though phages have been detected with polymerase chain reaction (PCR) assays in frozen meats, they either did not exhibit lytic activity, were apparently unstable, or simply more difficult to propagate (Janež et al., 2014; Jäckel et al., 2017). Solid samples can be incubated in sodium chloride/magnesium sulfate (S.M.) buffer to resuspend the phages, and the use of a homogenizer, such as a Stomacher ${ }^{\circledR}$, to remove phages from chicken skin provides the best results (Jäckel et al., 2019). Following the centrifugation of the resuspended samples and consequent filtration ( 0.45 and $0.22 \mu \mathrm{m}$ ) of the supernatant, samples can be scanned for lytic activity (Jäckel et al., 2019). The phages are then concentrated to a 10 -fold concentration using centrifugal filter units before spotting on indicator strains (Jäckel et al., 2019). Pre-screening to discriminate group II and group III phages rapidly may be beneficial. Using PCR, Jäckel et al. (2017) distinguished over 45\% of total phages as group II or III phages. PCR positive samples that do not show lytic activity with the indicator strain can be tested with other potential strains. Likewise, the PCR negative samples should be examined for lytic activity as they may contain rare group I phages (Jäckel et al., 2017).

The choice of a bacterial host is essential while harvesting the phages. C. jejuni NCTC12662 (PT14) is generally used as an indicator strain because it is vulnerable to a broad range of phages, although little is known about its response to phage infection (Hansen et al., 2007; Sørensen et al., 2015; Gencay et al., 2018). PT14 was isolated from chicken ceca, and its complete genome has been sequenced (Brathwaite et al., 2013; Sørensen et al., 2015). Nonetheless, a broad range of candidate host strains consisting of several fla-types and Penner serotypes should be considered since group II binds to receptors on the flagellum and group III phages binds to CPS receptors (Sails et al., 1998; Hammerl et al., 2011; Sørensen et al., 2011, 2015; Sorensen et al., 2017; Gencay et al., 2018). Sorensen et al. (2017) developed a protocol to determine receptor dependency of Campylobacter phages.

Jäckel et al. (2019) suggested that cultivation of indicator strains be via Campylobacter media in flasks rather than tubes, as amplification of bacteria is increased by an ample surface headspace for gas exchange. The selection of an overlay agar, such as NZCYM, is critical for the results of the activity tests and should include $\mathrm{CaCl}_{2}$ and $\mathrm{MgSO}_{4}$, which enable the attachment of phages to their host cell (Sails et al., 1998; Frost et al., 1999; Sambrook and Russell, 2001). Determination of lytic activity can be achieved via plaque assays and microplate tests (Fischer et al., 2013). In addition, to obtain single plaques, dilutions of phage preparations must be plated. The plaques formed by lytic Campylobacter phages are generally about one millimeter in diameter and somewhat turbid, so a zoom stereo microscope may be helpful to spot and count plaques (Jäckel et al., 2019). Specific phages may then be recovered by three sequential single plaque isolations (Hammerl et al., 2011; Jäckel et al., 2015).

Optimal propagation technique should be determined for each phage as propagation methods are not equally suited for all Campylobacter phages (Hammerl et al., 2011; Jäckel et al., 2015; Gencay et al., 2017; Sorensen et al., 2017). Propagation of lytic phages can be accomplished by either infection of bacterial cultures or creating agar plates and demonstrating confluent lysis (Green and Sambrook, 2012). Hammerl et al. (2011, 2014) and Jäckel et al. $(2015,2019)$ achieved over $10^{8} \mathrm{PFU} / \mathrm{mL}$ by infecting $100 \mathrm{~mL}$ cultures of the indicator strain with OD588 of approximately 0.4 with phages at a multiplicity of infection (MOI) of 0.01 followed by incubation for $12-24 \mathrm{~h}$ at $42^{\circ} \mathrm{C}$. 


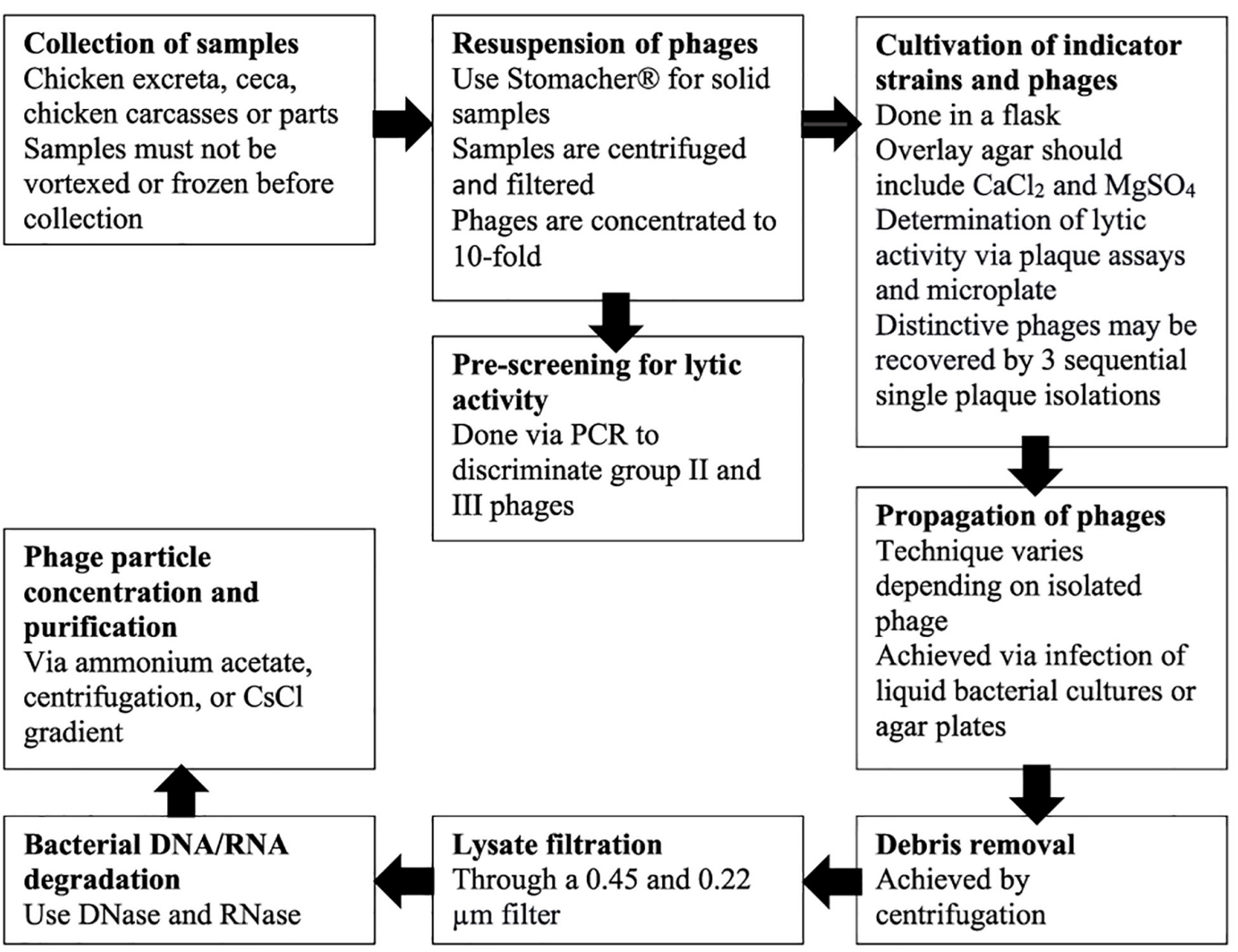

FIGURE 1 | Outline of main concepts of isolation, propagation, concentration, and purification of Campylobacter phages.

The cultures that appear to grow best in a flask with a filtered stopper can be placed in a box with a gas-producing sachet to mimic ideal growth conditions and incubated while mildly shaken (Jäckel et al., 2019). Since it is not recommended to use high centrifuge force, there is a possibility that remnants of agar can remain, which in turn may worsen filtration. This method has the additional benefit that the mass lysate does not include any agar, which may interfere with filtration (Jäckel et al., 2019). However, in another technique utilized by Loc Carrillo et al. (2007), Owens et al. (2013), and Gencay et al. (2017), the overlay agar is not harvested; instead, the visible plaques are extracted and suspended in buffer using the typical steps described by Frost et al. (1999).

Before the lysate is filtrated through a 0.45 and $0.22 \mu \mathrm{m}$ filter, the residual agar, cells, and debris are removed by centrifugation (Jäckel et al., 2019). Bacterial DNA and RNA are then degraded using $20 \mathrm{mg} / \mathrm{mL}$ of DNase, and RNase added to the lysate and incubated at $37^{\circ} \mathrm{C}$ for $30-60 \mathrm{~min}$ (Jäckel et al., 2019). Phage particles can be subsequently concentrated using a variety of techniques depending on the amount of the lysate, such as ammonium acetate purification done by Ackermann (2009), centrifugal force utilized in Loc Carrillo et al. (2007), or $\mathrm{CsCl}$ density gradient done by Hammerl et al. (2011) and Jäckel et al. (2015). CsCl density gradient is also used to purify Campylobacter phages, where the application of $10^{9}$ phage particles is suggested to obtain a prominent band (Jäckel et al., 2019). The extracted phages can consequently be applied to various studies such as morphological typing, selection of host range, and genomic or protein analysis.

\section{ISOLATION AND ANALYSIS OF CAMPYLOBACTER PHAGE DNA}

All sequenced Campylobacter phages have double-stranded DNA (Hammerl et al., 2011; Jäckel et al., 2015, 2019; Harada et al., 2018). Furthermore, genomic differences between group II and group III phages affect the choice of DNA extraction method (Hammerl et al., 2011; Jäckel et al., 2015, 2019). For instance, although the standard protocol described by Green and Sambrook (2012) is suitable for the extraction of group II DNA, the use of phenol-chloroform fails in the extraction of group III DNA (Hammerl et al., 2011; Jäckel et al., 2015, 2019). Commercially available kits for phage DNA extraction are available for both phage groups. 
Campylobacter is resistant against digestion by numerous restriction endonucleases, such as AvaII, BamHI, CIaI, EcoRV, EcoRI, HaeIII, Hinfl, HindIII, HpaIII, PstL, PvuIl, Rsal, and Scal (Sails et al., 1998). However, PFGE analysis using restriction endonucleases that cut pure A/T sequences, such as Dral, Smil, or Vspl, can be performed to establish the genome size of the phages and to assign them to their respective groups (Loc Carrillo et al., 2007; Hammerl et al., 2011; Sorensen et al., 2017). Restriction patterns can subsequently be analyzed on standard agarose gel yielding a more rapid and cost-effective evaluation. Jäckel et al. (2019) suggest applying DreamTaq DNA polymerase amplification constituents or whole genome amplification kits for phage DNA amplification such as those used by Hammerl et al. (2011). To date, all Campylobacter phage genomes have been sequenced by short-read sequencing, which is predisposed to homopolymer errors (Jäckel et al., 2019). Long DNA repeats that occur in group II phages hinder the assembly of reads using short-read sequencing. Long-read sequencing platforms such as PacBio or MinION can resolve the problem but necessitate a high amount of DNA (2-10 g) of phages, which can be challenging to obtain (Jäckel et al., 2019).

\section{POULTRY PREHARVEST CAMPYLOBACTER PHAGE THERAPY}

Research is ongoing to reduce pathogen occurrence on poultry farms for Campylobacter (Deng et al., 2020). Decreasing pathogen concentrations on poultry farms can affect the reduction of pathogen populations entering the food chain. Preharvest strategies include successful oral application of phages to reduce C. jejuni colonization in birds (Figure 2; Carvalho et al., 2010) and phages against $C$. jejuni as an alternative feed additive (Kittler et al., 2013). The phage-bacterial interaction is a typical association in the chicken GIT. Lower levels of Campylobacter have been observed to innately occur in the ceca of chickens (5.1 $\log _{10} \mathrm{CFU} / \mathrm{g}$ ) in the presence of indigenous Campylobacter phages compared to those chickens' lacking phages in the ceca (6.9 $\log _{10} \mathrm{CFU} / \mathrm{g}$ ) (Atterbury et al., 2005). Thus, the majority of preharvest intervention strategies of Campylobacter are focused on the reduction or removal of the microorganism from the ceca (Callaway et al., 2004; Hermans et al., 2011; Wheeler et al., 2014; Kim et al., 2019; Deng et al., 2020).

Bacteriophage treatment of Campylobacter in chickens was first reported by Loc Carrillo et al. (2005) and Wagenaar et al. (2005). Wagenaar et al. (2005) studied the effects of preventative versus therapeutic phage applications. The study consisted of a 10-day phage treatment trial with the preventive group infected with C. jejuni on day four of phage treatment, whereas in the therapeutic group treatment with phage was administered on sixth day of C. jejuni infection. Both groups had at least a two $\log _{10} \mathrm{CFU} / \mathrm{g} C$. jejuni reduction, which tapered off within a week to one $\log _{10}$ lower than the untreated group. Wagenaar et al. (2005) compared single phage application versus a cocktail of group III phages via birds' oral administration (Table 2). In their study, while the initial reduction was only maintained for $48 \mathrm{~h}$, a one $\log _{10} \mathrm{CFU} / \mathrm{g}$ decrease was

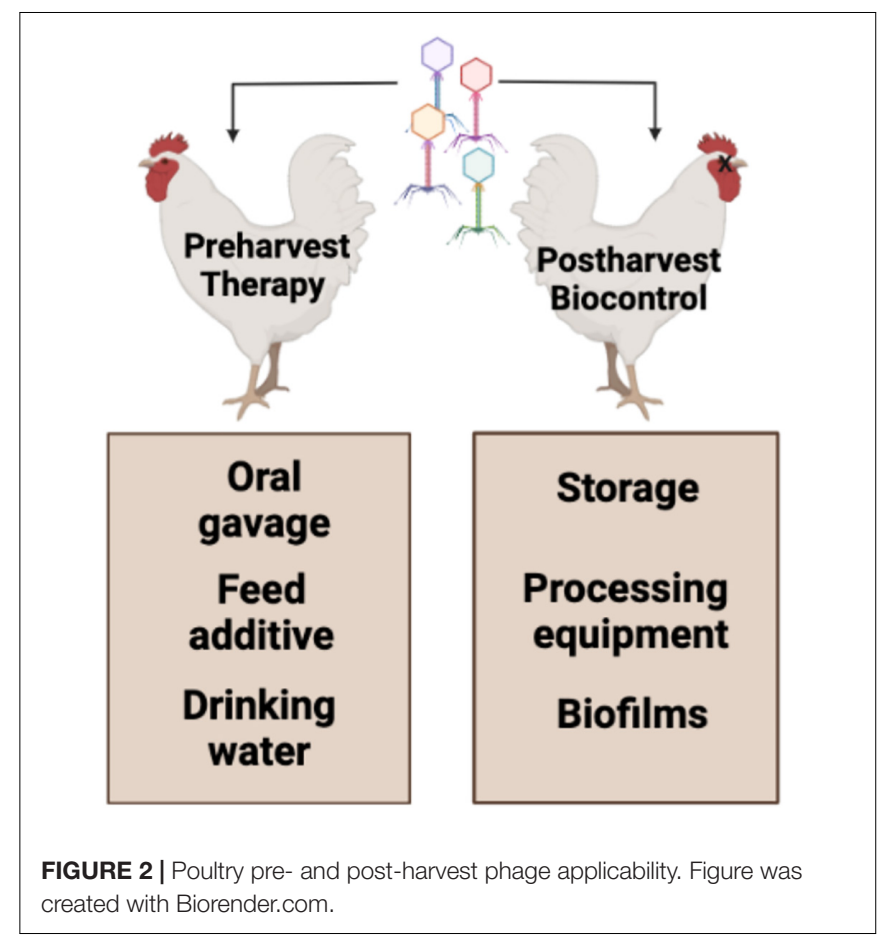

sustained after 30 days, independent of when the therapy was administered. In addition, the birds utilized in this study were at the age for slaughter (day 42), indicating that, despite the phage effectiveness peaking at $48 \mathrm{~h}$, Campylobacter concentrations could still be reduced in time for processing. More importantly, when Wagenaar et al. (2005) added another group III phage 69 along with phage 71 , they observed a $1.5 \log _{10} \mathrm{CFU} / \mathrm{g}$ reduction that eventually leveled off at one log lower than the untreated birds, which suggested a synergistic effect when phages were applied simultaneously (Wagenaar et al., 2005). Ultimately, Wagenaar et al. (2005) conducted the first in vivo study that indicated no signs of pathology to the chickens despite a dose phage administration. Although bacterial and phage strains were not obtained from the poultry meat or excreta, the model is not considered appropriate for broader remedial purposes in poultry manufacturing.

In the same year, Loc Carrillo et al. (2005) demonstrated that phage treatment of birds infected with $C$. jejuni reduced the cecal concentration of the marker strains by $0.5-5 \log _{10} \mathrm{CFU} / \mathrm{g}$ of cecal contents over 5 days compared to the control birds. The decrease in bacterial load was determined by the phage load, phage-Campylobacter grouping, and post-administration time (Loc Carrillo et al., 2005). Loc Carillo and associates used two group III Campylobacter phages (CP8 and CP34) in 25day old broilers administered via oral gavage with an antacid (Table 2). Interestingly, phage CP8 was active against one tested strain (C. jejuni GIIC8) and not the other (C. jejuni HPC5). In contrast, phage CP34 reduced both marker strains and sustained the reduction for 5 days (Loc Carrillo et al., 2005). Host strain specificity has been demonstrated as a potential therapeutic drawback of using Campylobacter phages. Few phages infect distinctive bacterial species, and the host range for most of them 
contains various strains of one bacterial species (Loc Carrillo et al., 2007). Similar to the Loc Carrillo findings, when phage CP8 tested against $C$. jejuni strain HPC5 in vitro, no statistically significant reduction was detected by Rabinovitch et al. (2003).

Multiplicity of infection is the ratio of adsorbed or infecting phages to predisposed hosts. Assuming the unlimited time for adsorption, the MOI ratio denotes the threshold of the infecting ratio (Abedon, 2011). Knowing the MOI value is essential for optimizing efficacy. For instance, when the MOI is too high, virions may inactivate through clumping and aggregation (Brown and Bidle, 2014; Roach and Debarbieux, 2017). In addition, MOI depends on the host-phage interaction and varies with medium, phage, and host (Brown and Bidle, 2014; Roach and Debarbieux, 2017). As such, an MOI above the point of saturation of infection, which is host-phage specific, may explain why a higher concentration of phages would not further reduce bacterial concentrations (Kasman et al., 2002; Rabinovitch et al., 2003; Brown and Bidle, 2014). Interestingly, Loc Carrillo et al. (2005) observed that the administration of $9 \log _{10}$ PFU was less effective than $7 \log _{10}$ PFU, which may be explained by potential phage aggregation and nonspecific association that can occur once the MOI is achieved. One notable drawback with the Loc Carrillo et al. (2005) and Wagenaar et al. (2005) studies is their phage therapy testing employed only one or two $C$. jejuni strains. While these studies demonstrated reductions in tested strains by phage therapy, they did not evaluate how the phage treatment would interact with a more diverse array of background Campylobacter strains.

El-Shibiny et al. (2009) utilized Campylobacter group II phage CP220 against C. jejuni and C. coli colonized 20-day old broilers and observed a $2-\log _{10} \mathrm{CFU} / \mathrm{g}$ reduction in cecal C. jejuni HPC5 populations in $48 \mathrm{~h}$ with a single $7-\log _{10} \mathrm{PFU}$ dose (Table 2). However, to accomplish a comparable decrease in C. coli OR12-colonized chickens, a 9-log PFU dose of CP220 was necessary (El-Shibiny et al., 2009). The critical distinction observed between CP220 and group III phages by El-Shibiny et al. (2009) demonstrated the ability of group II phages to lyse $C$. coli OR 12 and $30 \%$ of other broiler strains, including the ones that were not lysed by group III phages. A cocktail mixture of two groups could contribute to a broader host range to give the most coverage of Campylobacter species. Physiologically, C. coli and C. jejuni are similar with comparable cell wall structure and energy metabolism. The primary difference is the ability of $C$. jejuni to hydrolyze hippurate, a compound commonly detected in urine (Totten et al., 1987; Jauk et al., 2003). However, the genomes of C. jejuni and C. coli are approximately $12 \%$ divergent (Sheppard and Maiden, 2015). Thus, it may be possible for phages to infect and lyse C. coli but unable to replicate due to variations within the bacterial host cellular machinery. While the phenomenon has not been studied within Campylobacter phages, it has been observed that bacterial lysis can occur without phage propagation in the presence of a high MOI environment (Cairns et al., 2009; Abedon, 2011). Therefore, as El-Shibiny et al. (2009) suggested, this may offer a possible explanation for the need of a higher concentration of phages to reduce C. coli populations compared to C. jejuni populations.
The route of phage administration was examined by Carvalho et al. (2010). In their study the authors evaluated the success of the two different paths for phage application via oral gavage or feed intake (Table 2). In the first study, an orally gavaged cocktail of three broad-spectrum phages (phiCcoIBB35, phiCcoIBB37, phiCcoIBB12) was administered to 1-week-old birds infected with C. jejuni $2140 \mathrm{CD} 1$. In the second study, Carvalho et al. (2010) compared the oral gavage route and application of phages in feed on birds colonized with C. coli A11. Administration of phages via the feed route resulted in a higher reduction of Campylobacter fecal counts versus the oral route 4 days post administration (Table 2; Carvalho et al., 2010). The results of the Carvalho et al. (2010) study indicated that a successful reduction of the two most prevalent Campylobacter strains in poultry is possible through the administration of a phage cocktail. In addition, better reduction of Campylobacter counts via feed intake is advantageous. It is a simple and more practical method of applying phage therapy on farms than oral gavage.

Another route of phage therapy where the cocktail was administered through the drinking water was assessed by Kittler et al. (2013). Despite utilizing the same feed, vaccinations, and living conditions, phages were only significantly effective in reducing Campylobacter in one of the three trials, where Campylobacter populations were reduced below the detection limit in fecal samples (less than 50 CFU/g) (Kittler et al., 2013). Within 1 day of phage administration via drinking water C. jejuni cecal counts decreased more than three $\log _{10} \mathrm{CFU} / \mathrm{g}$ in the cecal contents. Three days post administration, at slaughter, Campylobacter counts were still reduced by $1.66-2.14 \log _{10}$ CFU/g (Kittler et al., 2013; Table 2). Similar to previously described studies, at least one $\log _{10}$ Campylobacter reduction could be detected 6 days post-administration, indicating successful self-replication and pathogen biocontrol (Table 2).

Fischer et al. (2013) compared the combinatory effect of a four-phage cocktail to a single phage administration versus $C$. jejuni counts over time. Using group III one phage or a fourphage cocktail administered at eight time points over 4 weeks directly into the crop of broilers, Campylobacter concentrations within the ceca were monitored over days $1,3,7,14,21,28,35$, and 42 after phage application (Fischer et al., 2013). Over time, significant reductions were observed, with the highest decrease being $\log _{10} 2.8$ CFU Campylobacter/g of cecal contents on day 21 in both groups (Fischer et al., 2013). When the phage was utilized in a cocktail containing an additional three phages, no significant differences between the cocktail treatment and the single phage treatment were observed (Fischer et al., 2013). The drawback of the study is that Fischer et al. (2013) only used group III phages in a cocktail, which may explain no significant difference when compared to the one phage application. Because the group III phages bind to the same receptors on Campylobacter and the phages replicate based on bacterial density, this may explain why the use of group III phages as cocktail and a single phage could produce similar results.

Hammerl et al. (2014) compared combinations of group II (CP68) and III phages with a cocktail of only group III phages (CP14 and CP81) administered via oral gavage against Campylobacter (Table 2). While a combination of group III 
TABLE 2 | Campylobacter phage treatments during in vivo preharvest studies.

\begin{tabular}{|c|c|c|c|c|c|c|c|c|c|}
\hline Phage & Group & Source & Administration & Flock age & $\begin{array}{l}\text { Campylobacter } \\
\text { spp. }\end{array}$ & Outcome & $\begin{array}{l}\text { Developed } \\
\text { resistance }\end{array}$ & $\begin{array}{l}\text { Time of sustained } \\
\text { reduction }\end{array}$ & Study \\
\hline $\begin{array}{l}\text { Phage } 71 \text { (NCTC } \\
\text { 12671) }\end{array}$ & Group III & NCTC & $\begin{array}{l}\sim 10^{10} \mathrm{PFU} \text { by oral } \\
\text { gavage }\end{array}$ & 32 days & C. jejuni C356 & $\begin{array}{l}3 \log _{10} \mathrm{CFU} / \mathrm{g} \text { reduction in } \\
24 \mathrm{~h} \text { in cecal contents }\end{array}$ & $\mathrm{n} / \mathrm{a}$ & $\begin{array}{l}1 \text { log sustained reduction } \\
\text { over } 30 \text { days compared to } \\
\text { control in both trials }\end{array}$ & $\begin{array}{l}\text { Wagenaar } \\
\text { et al., } 2005\end{array}$ \\
\hline $\begin{array}{l}\text { Phage 71, Phage } \\
69\end{array}$ & Group III & & $\begin{array}{l}\sim 10^{10} \text { PFU by oral } \\
\text { gavage }\end{array}$ & & C. jejuni C356 & $\begin{array}{l}1.5 \log _{10} \mathrm{CFU} / \mathrm{g} \text { initial } \\
\text { reduction }\end{array}$ & & & \\
\hline CP8 & Group III & $\begin{array}{l}\text { Broiler chicken } \\
\text { excreta, free-range } \\
\text { layer chicken } \\
\text { excreta, processed } \\
\text { chicken meat }\end{array}$ & $\begin{array}{l}7 \log _{10} \text { PFU by oral } \\
\text { gavage }\end{array}$ & 25 days & C. jejuni GIIC8 & $\begin{array}{l}5.6 \log _{10} \mathrm{CFU} / \mathrm{g} \text { cecal } \\
\text { content }\end{array}$ & $<4 \%$ & $\begin{array}{l}2.1-1.8 \log _{10} \text { sustained } \\
\text { reduction for } 5 \text { days }\end{array}$ & $\begin{array}{l}\text { Loc Carrillo } \\
\text { et al., } 2005\end{array}$ \\
\hline CP34 & Group III & & $\begin{array}{l}7 \log _{10} \text { PFU by oral } \\
\text { gavage }\end{array}$ & & C. jejuni HPC5 & $\begin{array}{l}3.9 \log _{10} \mathrm{CFU} / \mathrm{g} \text { cecal } \\
\text { counts }\end{array}$ & & & \\
\hline CP220 & Group II & Poultry sources & $\begin{array}{l}7 \log _{10} \text { PFU by oral } \\
\text { gavage }\end{array}$ & 20 days & C. jejuni HPC5 & $\begin{array}{l}2.1 \log _{10} \mathrm{CFU} / \mathrm{g} \text { reduction } \\
24 \mathrm{~h} \text { post phage }\end{array}$ & $2 \%$ & $\begin{array}{l}2 \log _{10} \text { sustained reduction } \\
\text { for } 2 \text { days }\end{array}$ & $\begin{array}{l}\text { El-Shibiny } \\
\text { et al., } 2009\end{array}$ \\
\hline CP220 & Group II & & $\begin{array}{l}9 \log _{10} \text { PFU by oral } \\
\text { gavage }\end{array}$ & & C. coli OR12 & $2 \log _{10}$ reduction & & & \\
\hline $\begin{array}{l}\text { PhiCcolBB35, } \\
\text { PhiCcolBB37, } \\
\text { PhiCcolBB12 }\end{array}$ & Group II & $\begin{array}{l}\text { Poultry intestinal } \\
\text { contents }\end{array}$ & $\begin{array}{l}1 \times 10^{6} \mathrm{PFU} \\
\text { phage cocktail by } \\
\text { oral gavage or } \\
1.5 \times 107 \mathrm{PFU} \\
\text { through feed }\end{array}$ & 7 days & $\begin{array}{l}\text { C. jejuni } 2140 \text { CD1 } \\
\text { and C. coli A11 }\end{array}$ & $\begin{array}{l}1.25 \log _{10} \mathrm{CFU} / \mathrm{g} \text { reduction } \\
\text { in feces by oral gavage } \\
2 \text { days post administration; } \\
2 \text { log10 CFU/g reduction in } \\
\text { feces by feed route } 2 \text { days } \\
\text { post administration }\end{array}$ & $13 \%$ & $\begin{array}{l}1.7 \log _{10} \text { CFU/g sustained } \\
\text { reduction in feces by oral } \\
\text { gavage } 7 \text { days post } \\
\text { administration; } 2 \text { log } 10 \\
\text { CFU/g sustained reduction } \\
\text { in feces by feed route } \\
7 \text { days post administration }\end{array}$ & $\begin{array}{l}\text { Carvalho } \\
\text { et al., } 2010\end{array}$ \\
\hline $\begin{array}{l}\text { NCTC } 12672, \\
\text { NCTC 12673, } \\
\text { NCTC 12674, } \\
\text { NCTC } 12678\end{array}$ & Group III & NCTC & $\begin{array}{l}\text { Phage cocktail of } \\
7.4 \log _{10} \text { PFU/bird } \\
\text { via drinking water }\end{array}$ & $36 d$ & $\begin{array}{l}\text { C. jejuni NCTC } \\
\text { 12661, C. jejuni } \\
\text { NCTC 12664, } \\
\text { C. jejuni NCTC } \\
\text { 12660 }\end{array}$ & $\begin{array}{l}3.2 \text { log CFU/g reduction in } \\
\text { cecal content compared to } \\
\text { control } 1 \text { day post } \\
\text { administration }\end{array}$ & $\mathrm{n} / \mathrm{a}$ & $\begin{array}{l}1.66-2.14 \mathrm{PFU} / \mathrm{g} \text { sustained } \\
\text { reduction in cecal content } \\
6 \text { days post administration }\end{array}$ & $\begin{array}{l}\text { Kittler et al., } \\
2013\end{array}$ \\
\hline NCTC 12673 & Group III & NCTC & $\begin{array}{l}10^{7} \mathrm{PFU} \text { into crop } \\
\text { of broiler }\end{array}$ & $9 d$ & C. jejuni 1474-06 & $\begin{array}{l}1.3 \mathrm{CFU} / \mathrm{g} \log _{10} \text { reduction } \\
\text { of cecal contents } \\
\text { compared to control up to } \\
3 \text { days post administration }\end{array}$ & Initially $43 \%$ & $\begin{array}{l}2.8 \log _{10} \text { sustained } \\
\text { reduction } 21 \text { days post } \\
\text { administration in trial II }\end{array}$ & $\begin{array}{l}\text { Fischer } \\
\text { et al., } 2013\end{array}$ \\
\hline $\begin{array}{l}\text { NCTC } 12673, \\
\text { NCTC } 12674, \\
\text { NCTC } 12678, \\
\text { NCTC } 12672\end{array}$ & Group III & NCTC & $\begin{array}{l}\text { Phage cocktail of } \\
10^{7} \mathrm{PFU} \text { directly } \\
\text { into crop of broiler }\end{array}$ & & C. jejuni 1474-06 & $\begin{array}{l}1.3 \mathrm{CFU} / \mathrm{g} \log _{10} \text { reduction } \\
\text { of cecal content compared } \\
\text { to control }\end{array}$ & Initially $24 \%$ & & \\
\hline CP14 & Group III & $\begin{array}{l}\text { Chicken fecal } \\
\text { samples of organic } \\
\text { origin }\end{array}$ & $\begin{array}{l}5 \times 10^{8} \mathrm{PFU} \text { by } \\
\text { oral gavage }\end{array}$ & 27 days & C. jejuni 3871 & $\begin{array}{l}1 \log _{10} \text { reduction of cecal } \\
\text { contents }\end{array}$ & $5 \%$ & $\begin{array}{l}\text { C. jejuni counts increased } \\
4 \text { days post administration }\end{array}$ & $\begin{array}{l}\text { Hammerl } \\
\text { et al., } 2014\end{array}$ \\
\hline
\end{tabular}




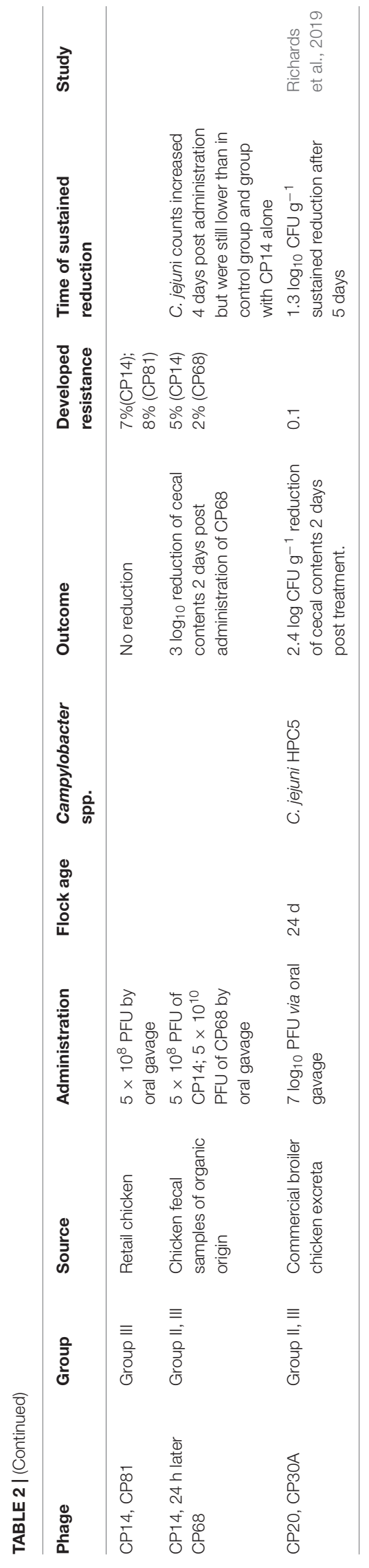

phages did not elicit a detectable $C$. jejuni reduction, application of CP14 phage alone achieved one $\log _{10} \mathrm{CFU} / \mathrm{g}$ reduction. These results were similar to the reduction of Campylobacter counts achieved by Wagenaar et al. (2005) using only one phage cocktail. However, Hammerl et al. (2014) observed that a sequential combination of $\mathrm{CP} 14$ phage followed by $\mathrm{CP} 68$ phage led to a three $\log _{10} \mathrm{CFU} / \mathrm{g}$ Campylobacter reduction in the cecal contents. Similar to the observations of El-Shibiny et al. (2009), Hammerl et al. (2014) concluded that phage cocktails should be composed of group II and group III phages to successfully combat Campylobacter.

Furthermore, Richards et al. (2019) showed that the utilization of phage therapy offers a minimal targeted intervention that is not harmful to the intestinal microbiota of broilers. Richards et al. (2019) demonstrated that a cocktail of CP30A and CP20 phages against $C$. jejuni colonized birds produced significant reductions in intestinal C. jejuni populations compared to control birds over 5 days and did not affect the alpha-diversity and richness of microbiota in ceca and ileum of birds compared to control (Table 2). The phage cocktail produced the most Campylobacter reduction in the ceca where the bacterial counts were decreased by $2.4 \log _{10} \mathrm{CFU} / \mathrm{g}$. The bacterial reductions were also significant in ileum (1.36 $\log _{10} \mathrm{CFU} / \mathrm{g}$ on day 2$)$ and colon (1.74 $\log _{10} \mathrm{CFU} / \mathrm{g}$ on day 3). Richards et al. (2019) were able to recover both phages of the cocktail for 5 days throughout the experiment in all three compartments of the chicken's GIT, indicating successful selfreplication in vivo and no competition between phages allowing them to co-exist. Overall, the time of phage application to limit Campylobacter colonization in chickens have been shown to be most effective over a 2- or 3-day period post phage administration (Loc Carrillo et al., 2005; El-Shibiny et al., 2009; Richards et al., 2019). In addition, when the time to slaughter after phage application was prolonged, numerous studies showed that cecal Campylobacter counts did not reach the counts detected in nontreated controls (Table 2). These findings suggest that phages' success of self-replication is possible in vivo and can provide an antimicrobial safety net in cases when a slaughter day may be postponed. In addition, the diminished competitive advantage of the resistant types, as reported by Loc Carrillo et al. (2005), reinforces the hypothesis of Wagenaar et al. (2005) that the release of potent Campylobacter phages into the environment would not comprise any more significant risk.

Achieving complete elimination of Campylobacter in the bird GIT may be unrealistic with phage therapy for various reasons. However, the partial reduction could still be a productive outcome for reducing potential exposure to Campylobacter. This possible reduction can be estimated using quantitative microbial risk assessment (QMRA), which is the probability of infection and illness when a population (usually of humans) is exposed to pathogens in the environment (Chapman et al., 2016). QMRA is based on hazard identification, exposure assessment, dose-response, and risk characterization (Vose, 2008). Based on this approach, quantitative risk assessment models suggest that reducing two $\log _{10} \mathrm{CFU} / \mathrm{g}$ of Campylobacter in the ceca at the time of slaughter would significantly impact campylobacteriosis's human incidence by approximately 30 fold (Rosenquist et al., 2003). Understanding how reductions 
in Campylobacter populations impact disease occurrence is essential, as, in nature, phages seldom eradicate their host bacterium populations (Connerton et al., 2008). The inability of complete microbial elimination may partly be due to natural bacterial resistance and the failure of phage particles to find host cells when occurring in low concentrations (Chibani-Chennoufi et al., 2004). Low concentrations of host cells should not be a concern when considering phage remediation in the ceca of broilers, as Campylobacter concentrations in the ceca often range from 4 to $8 \log _{10} \mathrm{CFU} / \mathrm{g}$ (Rudi et al., 2004).

\section{POULTRY POSTHARVEST CAMPYLOBACTER PHAGE BIOCONTROL}

Postharvest application of lytic phages could selectively target Campylobacter populations without interfering with the remaining microbiota. Phage treatment can be used to inactivate Campylobacter attached to food contact surfaces or grown as biofilms. Campylobacter bacteriophages isolated from retail poultry have been used in some post slaughter experiments (Umaraw et al., 2017). While Campylobacter phages have been isolated from poultry carcasses, they occur in relatively low concentrations compared to the Campylobacter bacterial loads that have been reported on poultry skin in retail environments up to $10^{4} \mathrm{CFU}$ per carcass (Dufrenne et al., 2001; Atterbury et al., 2003a; Scherer et al., 2006).

Campylobacter species can often be isolated from chicken skin and feathers, because the chicken skin has a protective effect on Campylobacter and other pathogens (Humphrey and Lanning, 1987; Berrang et al., 2000; Whyte et al., 2001; Atterbury et al., 2003a). This phenomenon is most likely due to the presence of feather follicles and skin folds that contain oils and fats that may protect bacterial cells from crystalizing during the freezing process. Since the infective dose of Campylobacter for humans is less than 500 cells, the research on the persistence of Campylobacter on chicken skin under freezing conditions is a significant food safety concern (Black et al., 1988). One of the approaches in the industry to decrease broiler carcass contamination includes the use of hyperchlorite in scald water and chillers (Atterbury et al., 2003a). However, this approach has been demonstrated to not significantly reduce pathogen loads, such as Campylobacter (Whyte et al., 2001). In addition, increasing the dilution of hyperchlorite increases its efficacy but reduces the quality of the product, which is intolerable by consumers (Atterbury et al., 2003a).

Host-specific phages have been successfully used in preharvest operations to control enteric Campylobacter counts in poultry (Table 2). Using a single phage therapy, Atterbury et al. (2003a) demonstrated over a one $\log _{10} \mathrm{CFU} / \mathrm{cm}^{2}$ reduction of C. jejuni on chicken skin inoculated with $10^{6} \mathrm{CFU}$ of C. jejuni PT14 with the administration of $10^{7} \mathrm{PFU}$ of group III phage $\varphi 2$ when the skin was stored at $4^{\circ} \mathrm{C}$ for 10 days (Table 3). Atterbury et al. (2003a) reported an improved reduction to $2.5 \log _{10} \mathrm{CFU} / \mathrm{cm}^{2}$ during additional cold storage $\left(-20^{\circ} \mathrm{C}\right)$ of poultry skin, which was greater than the effect of cold storage without phage application. However, environmental conditions may have enhanced phage efficacy. It is commonly accepted that Campylobacter species cannot replicate at $4^{\circ} \mathrm{C}$, and Atterbury et al. (2003a) findings verified that premise since the number of C. jejuni populations on chicken skin without phage stored at $4^{\circ} \mathrm{C}$ for 10 days were reduced by one $\log _{10} \mathrm{CFU}$. There was no increase in phage counts on any of the chicken skins inoculated with Campylobacter, indicating that phages may not reduce Campylobacter counts in situ without bacterial replication. The subsequent rationalization for the reduction in Campylobacter cells is that during inoculation, a fraction of phages effectively adsorbed to the surface of the host but did not replicate until the bacterium became more metabolically active. Their data supported this concept since no reduction was observed in either Campylobacter concentration or phage number when the phage was mixed with a non-susceptible bacterial host. The authors concluded that a combinatory phage cocktail of a broad host range must be used for the therapy to be practical. More so, combining phage application with freezing may cause further reduction of Campylobacter on broiler carcasses. In another study, Goode et al. (2003) demonstrated a more significant reduction of $C$. jejuni counts with a phage application than C. jejuni counts without phage due to the low temperature alone. Ninety-five percent reduction of C. jejuni occurred on chicken skin via group III phage 12673 at $10^{6} \mathrm{PFU} / \mathrm{cm}^{2}$ inoculated with $10^{4} \mathrm{CFU} / \mathrm{cm}^{2}$ C. jejuni C222 and incubated for $24 \mathrm{~h}$ compared to a non-phage treated group that resulted in a $90 \%$ reduction of C. jejuni, which was statistically different. Similar to the results of Atterbury et al. (2003a), the phages were able to persist on chicken skin over $48 \mathrm{~h}$ at $4^{\circ} \mathrm{C}$. These results indicate that phage administration may lessen cross-contamination with pathogens from other carcasses and processing environments.

Improvement of efficacy with a decrease in temperature was also noted in other meat matrices. For example, the use of phage Cj6 on raw beef at $5^{\circ} \mathrm{C}$ with high $\mathrm{MOI}$ and high host density reduced C. jejuni by $2.4 \log _{10} \mathrm{CFU} / \mathrm{cm}^{2}$ in cooked meat and a $1.5 \log _{10} \mathrm{CFU} / \mathrm{cm}^{2}$ in raw beef (Bigwood et al., 2008; Table 3). Conversely, at a high host density and high $\mathrm{MOI}, 2.8 \mathrm{CFU} / \mathrm{cm}^{2}$ at $6 \mathrm{~h}$ post phage administration and $2.2 \log _{10} \mathrm{CFU} / \mathrm{cm}^{2}$ reductions at $24 \mathrm{~h}$ were observed on cooked and raw meat, respectively (Bigwood et al., 2008). However, at $24^{\circ} \mathrm{C}$ and a low host density, no significant reductions were observed even with a high MOI (Bigwood et al., 2008). The results were different from the Salmonella outcome in the same study where the introduction of Salmonella phage P7 produced a $4.7 \log _{10}$ CFU Salmonella reduction when incubated at $24^{\circ} \mathrm{C}$ with a high MOI and low host density in cooked meat and two $\log _{10}$ reduction in raw beef. The decrease of Salmonella populations in the presence of the phage demonstrated that at low host cell load and high phage MOI, the number of bacterial cells eliminated does not rely upon the host cell load. These findings were consistent with Bigwood et al. (2009). This study also noted that inactivation of Campylobacter by phages continued and increased with time for 8 days incubated at $5^{\circ} \mathrm{C}$ for both cooked and raw types of meat. This finding is essential, as ready-to-eat meats are usually consumed within 7 days of purchase (Gilbert et al., 2007). In further work, Bigwood et al. (2009) concentrated on applying 
TABLE 3 | Campylobacter phage treatments during the postharvest studies.

\begin{tabular}{|c|c|c|c|c|c|c|c|}
\hline Phage & Group & Source & Administration & Campylobacter inoculation & Results & Resistance & Study \\
\hline$\varphi 2$ & Group III & $\begin{array}{l}\text { NCTC 12674, } \\
\text { ACTC 35922-B2 }\end{array}$ & $10^{7} \mathrm{PFU} / \mathrm{cm}^{2}$ & $\begin{array}{l}10^{6} \mathrm{CFU} / \mathrm{cm}^{2} \text { C. jejuni PT14 on } \\
\text { chicken skin }\end{array}$ & $\begin{array}{l}4^{\circ} \mathrm{C} \\
>1 \log _{10} \mathrm{CFU} \text { reduction } 30 \mathrm{~min}, 3 \text { days, } 5 \text { days } \\
-20^{\circ} \mathrm{C} \\
2.3 \log _{10} \mathrm{CFU} \text { reduction } 5 \text { days post administration }\end{array}$ & None & $\begin{array}{l}\text { Atterbury } \\
\text { et al., 2003a }\end{array}$ \\
\hline $\begin{array}{l}\text { NCTC } \\
12673\end{array}$ & Group III & NCTC & $\begin{array}{l}10^{6} \mathrm{PFU} / \mathrm{cm}^{2} \text { on } \\
\text { chicken skin }\end{array}$ & $\begin{array}{l}10^{4} \mathrm{CFU} / \mathrm{cm}^{2} \mathrm{C} \text {. jejuni } \mathrm{C} 222 \text { on } \\
\text { chicken skin }\end{array}$ & $\begin{array}{l}4^{\circ} \mathrm{C} \text { non-phage } \\
90 \% \text { reduction } 24 \mathrm{~h} \text { post administration } \\
4^{\circ} \mathrm{C} \text { with phage } \\
95 \% \text { reduction } 24 \mathrm{~h} \text { post administration }\end{array}$ & $\mathrm{n} / \mathrm{a}$ & $\begin{array}{l}\text { Goode et al., } \\
2003\end{array}$ \\
\hline Cj6 & $\begin{array}{l}\text { Group not } \\
\text { specified }\end{array}$ & Chicken feces & high $\mathrm{MOI}\left(10^{4}\right)$ & $\begin{array}{l}10^{4} \mathrm{~cm}^{-2} \text { of } C \text {. jejuni FGCSCFT } \\
\text { onto cooked or raw beef }\end{array}$ & 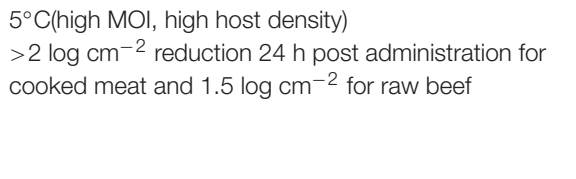 & $n / a$ & $\begin{array}{l}\text { Bigwood } \\
\text { et al., } 2008\end{array}$ \\
\hline Cj6 & $\begin{array}{l}\text { Group not } \\
\text { specified }\end{array}$ & Chicken feces & $10^{2}-10^{8} \mathrm{PFU} \mathrm{mL}^{-1}$ & $\begin{array}{l}10-10^{4} \mathrm{CFU} \mathrm{\textrm {mL } ^ { - 1 }} \text { of } C \text {. jejuni into } \\
\text { tube with inoculum }\end{array}$ & $\begin{array}{l}24^{\circ} \mathrm{C} \text { and } 2 \mathrm{~h} \text { post administration: } \\
1.8 \times 10^{5} \mathrm{PFUmL}^{-1} \\
3-8 \% \text { reduction } \\
1.2 \times 10^{6} \mathrm{PFUmL}^{-1} \\
33-52.3 \% \text { reduction } \\
1.1 \times 10^{7} \mathrm{PFUmL}^{-1} \\
>96 \% \text { reduction } \\
\text { Without phages } \\
8.9 \% \text { reduction }\end{array}$ & $\mathrm{n} / \mathrm{a}$ & $\begin{array}{l}\text { Bigwood } \\
\text { et al., } 2009\end{array}$ \\
\hline \multirow[t]{6}{*}{$\begin{array}{l}\mathrm{CP} 8 \text { or } \mathrm{CP} \\
30\end{array}$} & Group III & Poultry excreta & $10^{6}$ or $10^{9} \mathrm{PFU} / \mathrm{ml}$ & $\begin{array}{l}\text { C. jejuni NCTC } 11168 \text { or PT14 at } \\
10^{5} \mathrm{CFU} / \mathrm{ml} \text { incubated at } 37^{\circ} \mathrm{C} \text { for } \\
5 \text { days grown in biofilms on glass }\end{array}$ & $\begin{array}{l}\text { In biofilms: } \\
\text { CP30 or CP8 versus } 11168 \text { or PT14 }\end{array}$ & $\begin{array}{l}\text { NCTC } 11168 \text { à } \\
\text { CP8 (84\%) à CP30 } \\
(90 \%) \\
\text { None in PT14 }\end{array}$ & $\begin{array}{l}\text { Siringan } \\
\text { et al., } 2011\end{array}$ \\
\hline & & & & & $\begin{array}{l}3 \log _{10} \mathrm{CFU} / \mathrm{cm}^{2} \text { reduction } 2 \mathrm{~h} \text { post administration } \\
\mathrm{CP} 8 \text { versus } 11168 \\
\text { barely detectable limits } 24 \mathrm{~h} \text { post administration }\end{array}$ & & \\
\hline & & & & & $\begin{array}{l}\text { CP8 versus PT14 } \\
1 \log _{10} \mathrm{CFU} / \mathrm{cm}^{2} \text { reduction } 24 \mathrm{~h} \text { post administration }\end{array}$ & & \\
\hline & & & & & $\begin{array}{l}\mathrm{CP} 30 \text { versus } \mathrm{PT} 14 \\
2.5 \log _{10} \mathrm{CFU} / \mathrm{cm}^{2} \text { reduction } 4 \mathrm{~h} \text { post administration }\end{array}$ & & \\
\hline & & & & & Planktonic cells: & & \\
\hline & & & & & $\begin{array}{l}\text { CP30 versus PT14 } \\
<1 \log \mathrm{CFU} / \mathrm{cm}^{2} \text { reduction } 4 \mathrm{~h} \text { post administration }\end{array}$ & & \\
\hline$F 356+F 357$ & $\begin{array}{l}\text { Group not } \\
\text { specified }\end{array}$ & $\begin{array}{l}\text { Free range poultry } \\
\text { farms }\end{array}$ & $10^{7} \mathrm{PFU} / \mathrm{cm}^{2}$ & $\begin{array}{l}10^{4} \mathrm{CFU} / \mathrm{cm}^{2} \text { of } \mathrm{C} . \text { jejuni NCTC } \\
12662 \text { on chicken skin }\end{array}$ & $0.73 \log _{10}$ reduction at $5^{\circ} \mathrm{C} 24 \mathrm{~h}$ post administration & $\mathrm{n} / \mathrm{a}$ & $\begin{array}{l}\text { Zampara } \\
\text { et al., } 2017\end{array}$ \\
\hline
\end{tabular}


phage in the liquid food stored at room temperature for $2 \mathrm{~h}$, as it is considered the maximum time for food storage at room temperature (Table 3). At the lowest phage concentration, the number of surviving host bacteria was close to $100 \%$, but with the increasing concentration of phages, the inactivation of C. jejuni and Salmonella cells increased (Table 3). Decreased survival over time was observed for $C$. jejuni populations when the host concentration was low, indicating that with a given concentration of phages, the reduction of Campylobacter cells was more significant for lower concentrations of host bacterial cells.

In a more recent study, Zampara et al. (2017) demonstrated the application of lytic phages that targeted both CPS (group III) and flagella (group II) of C. jejuni on chicken skin under conditions that imitated a storage environment (Table 3). A combination of group III phages (F356 and F357) produced a $0.73 \log _{10}$ reduction of $C$. jejuni counts on chicken skin at $5^{\circ} \mathrm{C}$ in $24 \mathrm{~h}$. These results are in contrast to the results from CPS targeting phages used alone that produced a $0.55 \log _{10}$ reduction (F356) and $0.49 \log _{10}$ reduction (F357), and phage targeting the flagella (F379) that failed to reduce Campylobacter at a low temperature significantly. Previous studies have shown that motility may affect the infection proficiency of flagellotropic phages (Sørensen et al., 2015). Thus, the group II phage could be unsuccessful due to the potentially compromised motility of C. jejuni at lower temperatures. However, Zampara et al. (2017) observed that motility of C. jejuni was not a factor and further indicated that the temperature did not affect phage binding as no differences of phage binding between 37 and $5^{\circ} \mathrm{C}$ were observed within an hour of incubation. However, group III phages exhibited greater binding capacity with an average of $96 \%$ of phages adsorbing to the bacterial cells at $5^{\circ} \mathrm{C}$ after $24 \mathrm{~h}$ of incubation, compared to $55 \%$ of attached group II phages. The authors also observed an increase in free group II phage concentration after $24 \mathrm{~h}$ of incubation compared to $1 \mathrm{~h}$ incubation. They postulated that group II phages bound to the bacterial cell within the first hour but not permanently, explaining the increased concentration of free phages after $24 \mathrm{~h}$.

Most phage studies involve the Myoviridae family of Campylobacter phages. However, Huang et al. (2020) characterized and described a rare member of the Siphoviridae family, CAM-P21, isolated from the beef grind. CAM-P21 was described to possess a broad host range, a better titer, and enhanced performance under diverse stress conditions compared to the Myoviridae family of phages. CAM-P21 reduced viable C. coli counts by more than two logs after a $12-24 \mathrm{~h}$ incubation period at both 42 and $37^{\circ} \mathrm{C}$ in vitro, respectively (Huang et al., 2020). The findings reported by Huang et al. (2020) suggest that a prospective combination of families of phages in a cocktail can potentially control for multiple Campylobacter species.

A significant concern for processing facilities is the buildup of biofilms on processing surfaces and equipment (Arnold and Silvers, 2000). Campylobacter, along with other pathogens, can form biofilms by producing a polysaccharide matrix (Gunther and Chen, 2009). In comparison to chemical sanitizers such as chlorine and peracetic acid, which appeared to be inefficient in removing biofilms, several bacteriophages have successfully reduced pathogen populations within biofilms
(Deborde and Von Gunten, 2008; Siringan et al., 2011; Van der Veen and Abee, 2011). For example, bacteriophages CP8 and CP30 effectively reduced C. jejuni by one to three $\log _{10}$ in biofilms formed on glass surfaces (Siringan et al., 2011). While glass may not represent the surfaces typically found in poultry processing facilities, Siringan et al. (2011) detected a three $\log _{10} \mathrm{CFU} / \mathrm{cm}^{2}$ reduction within $2 \mathrm{~h}$ post phage administration in Campylobacter counts in biofilm incubated at $37^{\circ} \mathrm{C}$ using group II phages CP8 or CP30 (Table 3). However, bacterial cells were recovered at 4$8 \mathrm{~h}$ post phage administration that may be correlated with the reattachment of $C$. jejuni biofilm that was previously separated by phage treatment. Regardless of the final level of recovered Campylobacter cells after $4 \mathrm{~h}$, instantaneous effects of phage application could still be used to initiate the dispersal of biofilms in poultry processing that high-pressure water treatments could follow. Remarkably, application of CP8 on C. jejuni NCTC 11168 resulted in nearly undetectable counts 24 -h post phage application compared to C. jejuni PT14 strain, which produced a greater quantity of biofilm and exhibited less than one $\log _{10}$ $\mathrm{CFU} / \mathrm{cm}^{2}$ reduction over $24 \mathrm{~h}$ period in 11168 counts when CP8 phage was used. However, CP30 reduced C. jejuni PT14 counts by $2.5 \log _{10} \mathrm{CFU} / \mathrm{cm}^{2}$ in $4 \mathrm{~h}$ regardless of the excessive amount of biofilm matrix.

Interestingly, although CP30 showed such success on C. jejuni PT14 cells in biofilm, the phage produced less than one $\log _{10}$ $\mathrm{CFU} / \mathrm{cm}^{2}$ reduction in the planktonic cells under the same conditions. This finding contradicts previous observations by Sharma et al. (2005) that concluded similar effects of phages on attached and planktonic cells. Furthermore, similarly to several preharvest studies, there appeared to be stasis in phage concentration in biofilm and planktonic cultures throughout the experiment regardless of the reduced Campylobacter numbers. This phenomenon indicates a threshold above which phage counts do not increase despite being constantly supplemented into the matrix through replication. This could illustrate a passive biocontrol in which the quantity of phages is adequate to decrease cell counts without the necessity for excessive levels of phage replication.

Biofilms represent an accumulation of various cells enclosed by a matrix of extracellular polymeric substance (EPS) produced by bacterial members of the biofilm (Sillankorva et al., 2011). The main constituents of the EPS are long-chain sugars, DNA, and other various biological macromolecules that can be very diverse (Flemming, 2008). Bacteria within a biofilm have demonstrated high resistance to antibiotics and other antimicrobial agents (Harper et al., 2014). In addition, the concentration of the respective agent required to generate antimicrobial effects can be more than a thousand times higher than the amount necessary for free-living microorganisms (Ceri et al., 1999). Yet, bacteriophage application has shown high success in biofilm dispersal within bacterial species (Siringan et al., 2011).

Since biofilms' extracellular contents depend on the microbial populations present, phage cocktails should be evaluated against biofilms comprised of various bacterial genera. The success of specific phages in removing biofilms can be potentially due to polysaccharide depolymerase production, which breaks up the polysaccharide matrix (Hughes et al., 1998). For instance, 
many caudovirales, such as T4 and HK620 of E. coli, possess a polysaccharide depolymerase protein at the end of their tail that can degrade microbial capsules and allow cellular attachment (Harper et al., 2014). Lu and Collins (2007) engineered such a phage that stimulated host polysaccharide depolymerase expression resulting in the breakup of the polysaccharide matrix. They also reported that its application reduced E. coli biofilms by nearly $100 \%$ and produced a reduction two times better than non-enzymatic phage (Lu and Collins, 2007). The polysaccharide depolymerase expressing phages may improve efficacy in preharvest strategies where the sustained phage replication is less expected, such as the poultry GIT. However, host specificity insinuates that a thorough library of phages must be preserved so that a proper administration can be designated for each bacterial community within a biofilm. The possibility of combinations within biofilms suggests that it may be challenging for any created phage to be successful on a wide range of biofilms; although, the concept could work with other biofilm-destroying enzymes (Lu and Collins, 2007). Future developments for the strategy may incorporate several phage promoters amplifying enzyme production that would target multiple EPS constituents and target multiple bacterial species ( $\mathrm{Lu}$ and Collins, 2007). Unlike T7 E. coli phage, Campylobacter phages do not possess RNA polymerase and there are no strong promoters that have been identified within the Campylobacter phages, which would make genome cloning within the phage difficult.

\section{POTENTIAL CAMPYLOBACTER PHAGE HOST RESISTANCE MECHANISMS}

A potential concern of phage resistance arises from the increased or prolonged phage application for medical applications or in the food industry (Goodridge and Bisha, 2011). In the environment, bacteria and bacteriophages exist in a co-evolution cycle, in which phage-insensitive hosts survive or prevent phage predation by passing on the corresponding resistance mechanisms (Weinbauer, 2004; Labrie et al., 2010). Phage resistance usually arises due to the loss or modification of cell surface molecules, such as capsules, LPS, pili, or flagella (Labrie et al., 2010).

Labrie et al. (2010), Bradde et al. (2017), and Jiang and Doudna (2017) briefly described general phage resistance mechanisms. The mechanisms can be classified into two categories: (1) prevent initial phage interaction with the host and/or (2) survive phage infection. The former is commonly accomplished via modification of phage receptor sites, preventing DNA entry by changing the injection site conformation, and producing physical barriers through the extracellular matrix (Labrie et al., 2010). For instance, the MeOPN moiety of the CPS has been identified as a receptor site for lytic phages, such as F336 (Sørensen et al., 2011, 2012). Sørensen et al. (2012) observed phage resistance when the phase variable phosphoramidate $(\mathrm{MeOPN})$ moiety of CPS of C. jejuni was modified. In addition, over $70 \%$ of C. jejuni were found to possess modifications in their MeOPN moiety (McNally et al., 2007; Alphen et al., 2014). Although these surface structures often function as virulence factors and can contribute to bacterial survival, studies have shown that phage resistant $C$. jejuni have a competitive disadvantage in terms of fitness compared to phage sensitive isolates in the same environment without the phage's presence (Levin and Bull, 2004; Scott et al., 2007a,b; Carvalho et al., 2012; Hooton et al., 2020).

Scott et al. (2007b) showed that phage therapy affects the growth of resident Campylobacter in the avian GIT. Scott et al. (2007b) showed that amongst C. jejuni that survive phage infection in broiler chickens are phage-resistant types that exhibit genomic rearrangements. Scott et al. (2007b) investigated group III phage CP34 predation on C. jejuni HPC5 and R14-CampMu and R20-CampMu on R14 and R20 C. jejuni strains within the avian GIT and isolated phage-resistant mutants. These mutants were most likely not the dominant Campylobacter strain; since the mutations primarily altered the flagella, which caused a significant negative impact on colonization. The authors concluded that phage resistance is rare in poultry because the mutants that avoid phages are not capable of chicken GIT colonization and quickly mutate back to colonization-capable sensitive forms.

Prevention of phage infection is not the only bacterial response utilized. Other phage resistance mechanisms focus not on preventing phage entry but instead on bacterial host survival once infected by phage. Clustered regularly interspaced short palindromic repeats (CRISPR) have been studied extensively and provide a mechanism for bacteria to survive multiple phage infections (Barrangou et al., 2007). CRISPR loci are present in $45 \%$ of the bacteria, according to Grissa et al. (2007). Initially observed in E. coli and described by Ishino et al. (1987), CRISPR is an arrangement of short repeated sequences split by spacers with unique sequences and are located in plasmid and chromosomal DNA. These spacers are frequently the nucleic acids of plasmids and viruses (Rath et al., 2015). CRISPR activity involves the CRISPR-associated (cas) genes located adjacent to the CRISPR that code for proteins fundamental for the proper immune response (Barrangou et al., 2007). There are distinct types of CRISPR systems. C. jejuni NCTC 11168 and PT14 have been reported to contain subtype II-C CRISPR systems that lack Cas4 proteins (Dugar et al., 2013). While the absence of Cas4 has been noted in subtype II-C CRISPR systems, the protein has been shown to possess an exonuclease activity which is required for CRISPR adaptation (Shah et al., 2013). Thus, the deficiency of Cas4 may inhibit spacer integration, such as phage defense.

By studying carrier state life cycle (CSLC) of C. jejuni PT14 for CP8 and CP30A phages, Hooton and Connerton (2015) had the opportunity to assess the process of the CRISPR-Cas system in the company of Class III phage carrying Cas4. The CSLC represented a mixture of bacteria and phages in a state of equilibrium (Lwoff, 1953). Under CSLC conditions, phages could continue to associate with a well-suited host and generate free virions in a search for new hosts (Siringan et al., 2014). While a fraction of the bacteria attain resistance, some sensitive cells happen to maintain the phage population so that both survive (Siringan et al., 2014). Although appearing as lysogens, strains exhibiting CSLC do not integrate phage nucleic acid into the host genome (Siringan et al., 2014). In addition, CSLC has been strictly observed with the lytic phages, and there are several experimental 
examples of such relationships (Li et al., 1961; Jones et al., 1962; Jarling et al., 2004; Bastías et al., 2010). During their experiment, Hooton and Connerton (2015) observed that the carrier state populations was comprised of bacteria that had extended the CRISPR array by acquiring naive spacers. Markedly, all the new spacer sequences could be located in the host genome sequence and were not noted in either co-propagating phage genomes. This mechanism prevents phage DNA inclusion, which allows the phage to replicate undetected (Hooton and Connerton, 2015). The phenomenon indicates that even internal host resistance mechanisms can be complicated and mechanistically elusive to understand. The authors could not conclude how long bacteria carrying these spacers survived (Hooton and Connerton, 2015). Potentially, the CRISPR facilitated immunity is sustained in this setting as a self-sacrificing response to the constant exposure to phage infection but this still does not explain why the phage resides as a practical component of the system. Hooton and Connerton (2015) suggested that Campylobacter phages can use Cas4-like protein as an anti-CRISPR technique to initiate a spacer integration to use host DNA as an operational distraction to phage DNA. Therefore, Campylobacter that obtain self-spacers and avoid phage infection must overcome CRISPR-facilitated immunity against itself by either withstanding alterations in gene regulation or losing the interference functions exposing them to the foreign DNA invasion (Hooton and Connerton, 2015).

Other factors may be associated with phage resistance. It has been insinuated that the persistence of phage infection in microbial cultures could be facilitated by gradual adsorption rates of the phages, permitting the bacterial host time to replicate before the cellular machinery is overcome (Torsvik and Dundas, 1980). Remarkably, bacteriophages generated by Campylobacter CSLC strains retained phage adsorption constants comparable to those propagated by traditional lysis (Siringan et al., 2014). Siringan et al. (2014) showed that $70-90 \%$ of the phage population in Campylobacter CSLC strains were closely related with their host, either bound to CPS of the cell or preserved within the host cell with the potential that the phage genomes are carried as episomes (Siringan et al., 2014). Siringan et al. (2014) proposed that disbanded phage elements are associated with the bacteria, and the outcome of the phages is not subject to the fate of the host. Nevertheless, the authors also suggested that the presence of the phages is not totally passive, and that the host's replication contributed to the detected phage concentration. Phenotypic analysis of the CSLC Campylobacter strains showed that the cells were non-motile, and their flagella were shortened (Siringan et al., 2014). These findings are consistent with impaired motility of most phage-resistant types retrieved from post-infection cultures, where mutants with non-functional flagella have been shown not to establish phage infection (Coward et al., 2006; Scott et al., 2007a,b). Consequently, CSLC strains were incapable of colonizing chickens in the Siringan et al. (2014) study. These features make CSLC strains an essential ecological reservoir for phage propagation and conceivable commercial interest as a constant source of phages for remedial and biological sanitation purposes in the food and farming productions directed at reducing human exposure to Campylobacter.
An interesting observation was noted by Burmeister et al. (2020), indicating an evolutionary compromise between phage and antibiotic resistance in bacteria. When studying the interactions between phage and antibiotic resistance genes, Burmeister et al. (2020) observed increased antibiotic sensitivity in bacteria where the phage resistance emerged. The relationships between phages, antibiotic-resistant bacteria, and antibiotic-sensitive bacteria are complicated. Occasionally when phage resistance develops, the bacteria increase antibiotic sensitivity (Burmeister et al., 2020). To achieve a better understanding of these associations, Burmeister et al. (2020) screened 33 commercial and environmental E. coli phages for their dependence on the antibiotic efflux pump gene tolC. They identified phage U136, which depends on the core of the LPS and the antibiotic resistance gene tolC. Burmeister et al. (2020) also noted that U136B selects host mutants with genes encoding its essential host entry elements, tolC and LPS. These phage-resistant mutants exhibited phenotypic modifications to their tetracycline sensitivity, which was facilitated by $t o l C$, as well as colistin, stimulated by LPS associated elements, or both (Burmeister et al., 2020). These results demonstrate the potential to reverse the existing antibiotic resistance and potentially alleviate some of the public health problems associated with treatment by antibiotics.

Lysogenic bacteriophages of Campylobacter species have been the emphasis of numerous studies directed at comprehending the complicated relations that have become established between bacteria and viruses throughout the millions of years of coexistence (Hooton et al., 2020). Studying lysogenic phages of Campylobacter species have been used to assess different protein expression responses in host cells, genomic reshuffling, and methods of resistance to phage infection in Campylobacter species such as CRISPR-facilitated immunity and phase variation (Hooton et al., 2020). C. jejuni integrative elements (CJIE) and $\mathrm{Mu}$-like phage sequences have been previously detected in Campylobacter species (Parker et al., 2006; Scott et al., 2007b; Clark et al., 2012). Genomic rearrangements triggered by $\mathrm{Mu}$-like prophages are considered as main features for administering host resistance to phage infection (Hooton et al., 2020). It is commonly recognized that integrated phages can potentially change the virulence phenotype of the host (Brussow et al., 2004). For example, a study implicating C. jejuni encoding homologs of $\mathrm{Mu}-$ like phages (CJIE1) indicated increased adherence and invasion of cells compared to $C$. jejuni cells lacking integrated phage components (Clark et al., 2012). However, in an analogous study, no statistical differences were detected between the adhesion and presence of CJIE1-like elements (Skarp et al., 2017). In addition, genomic rearrangements by CJIE1-like prophages contributed to the host resistance to phage infection in Campylobacter and have been observed to hinder the host's ability to attain extracellular DNA through the natural transformation process (Scott et al., 2007b; Gaasbeek et al., 2009, 2010; Brown et al., 2015).

Campylobacter use various strategies to avoid phages, such as genetic rearrangements, utilization of alternate flagellin, phase variation, and attainment of CRISPR spacers to abolish phage predation (Scott et al., 2007b; Hooton and Connerton, 2015; Lis and Connerton, 2016; Gencay et al., 2018). More 
recently, researchers from Singapore-MIT Alliance for Research and Technology (SMART) discovered another new and remarkable type of bacterial defense system. The SspABCD-SspE phosphorothioate (PT) system is different from previously studied mechanisms. For instance, SspE protein inhibits phage replication by nicking the phage DNA rather than degrading dsDNA as seen in previous mechanisms and the protection against bacteriophages is stimulated by sequence-specific PTs (Xiong et al., 2020). Xiong et al. (2020) described this unique defense system for Vibrio cyclitrophicus, E. coli, and Streptomyces yokosukanensis, which have different genetic structures, metabolism, and phenotypes. These findings have expanded the understanding of the diversity of a bacterial defense system. In summary, when designing a phage therapeutic cocktail, the discovered bacterial defense mechanisms must be considered.

\section{CAMPYLOBACTER PHAGE RESISTANCE IN POULTRY PRODUCTION AND STRATEGIES FOR CIRCUMVENTION}

The use of phages to control Campylobacter in poultry deviates from the more clinical applications of phage therapy because the bacteria are not explicitly pathogenic in birds they reside as a part of the GIT. Campylobacter colonize the chicken intestine to a high density and are certainly an optimal phage therapy target (Connerton et al., 2011). However, concerns have been raised that Campylobacter will merely develop resistance to phages, making this strategy ultimately ineffective in the long term (Barrow, 2001). Although a multiplicity of spontaneous phage-resistant bacterial mutants develops in in vitro populations, resistance to phages has been associated with reduced virulence in vivo and reduced survival (Adams, 1959; Connerton et al., 2004; Loc Carrillo et al., 2005; Capparelli et al., 2010). Unlike bacterial resistance to bacteriostatic chemical agents, phages continually evolve to evade host barriers, leading to an evolutionary balance that allows both host and phage to multiply. To achieve success in phage therapy, modifying the balance in favor of phage serves as a momentary opportunity to reduce bacterial numbers, at least in the short term. For the application in preharvest procedures, the return to equilibrium can potentially be avoided by the slaughter of the birds while the Campylobacter populations are still reduced and have not yet recovered.

In practice, the required replication for successful phage treatment has its advantages and disadvantages. The benefits are that phage application is economical as there is no need to match the administration dose to the concentration of Campylobacter colonization in the bird because the phages will propagate according to the number of hosts present (El-Shibiny et al., 2009). A potential disadvantage is the possible development of bacterial host resistance due to the increased number of replications (ElShibiny et al., 2009). However, El-Shibiny et al. (2009) stated that this specific disadvantage did not appear to be a concern even 5 days post phage administration during their experiment. Furthermore, the authors hypothesized that the slaughter of birds 2 days following phage therapy would be the most optimal management approach by allowing phage replication and decrease the risk of developing bacterial resistance. Other in vivo preharvest studies support this approach (Table 2). Thus, phage application closer to the end of poultry production can mitigate selective pressure on Campylobacter and prevent the transmission of infection to other birds.

Another strategy to circumvent the potential problem of developing phage resistance is administering phages from different phage groups. Thus, group II and group III phages are capable of binding multiple host cell receptors (Coward et al., 2006; Sørensen et al., 2011). Hammerl et al. (2014) showed that the application of a phage cocktail consisting of the same group of phages contributed to a higher resistance frequency versus the application of one type of phage and a combination of different groups of phages (Table 2). However, the administration of group III phage alone or in combination with group II phage yielded a lower resistance rate than when applied in combination with another group III phage (Hammerl et al., 2014). In addition, Hammerl et al. (2014) observed that the resistance to group II phages was much more constant than resistance to phages of group III, which was similar to reports from other studies (Loc Carrillo et al., 2005; Fischer et al., 2013), where host cells rapidly reverted to susceptible types. Therefore, it would be beneficial to examine the resistance potential of all phages of a cocktail to construct the final cocktail of phages from different groups, which vary in their host ranges, lytic spectra, and resistance mechanisms. Furthermore, postharvest phage application to poultry meat may restrict the emergence of phage-resistant strains since $C$. jejuni cannot grow at lower temperatures (Atterbury et al., 2003a). Thus, phageresistant variants of $C$. jejuni cannot arise under these conditions (Atterbury et al., 2003a).

Several pathogens, such as C. jejuni have a phase variation (PV) mechanism that allows the bacterium to rapidly adapt to external environment, specifically for a host-associated bacteria, through modifications of surface structures (Sandhu et al., 2021; Sorensen et al., 2021; Yamamoto et al., 2021). PV occurs via hypermutation of simple sequence repeats (SSR) through slipped-strand mispairing during DNA replication (Sandhu et al., 2021). The PV mechanism involves differences of protein expression in an on-off fashion and is located within proteincoding regions within genes that regulate the expression of surface structures, such as CPS and flagella (Parkhill et al., 2000). PV can affect phage infection, as surface structures function as receptors for phages. Due to $\mathrm{PV}$, treatment of birds with phages have shown to produce high degree of resistance by modifications in the formation or expression of receptors (Sandhu et al., 2021).

Through computational analysis considering different mutational structures of the PV within C. jejuni and phage F336 interaction in a nutrient-controlled continuous culture system, Sandhu et al. (2021) studied how phage infections effect the evolution of PV in C. jejuni. The authors observed that extremely low and extremely high mutation rates are evolutionarily unfavorable and rather evolutionary stable mutation rates are affected by fluctuating density of the phage and the reduction of bacterial numbers. The equilibrium between counter-selection and phage infection can result in the progression of $\mathrm{PV}$ phage receptor and maintenance of the PV 
receptor-dependent phage (Sandhu et al., 2021). From a practical standpoint, Sandhu et al. (2021) predicted that introducing phage into the system with no continuing bacterial growth, such as in post-harvest applications, may result in nearly 10 -fold reduction in bacterial counts. Whereas pre-harvest application of F336 phage should be considered when counter-selection acts only on the phage resistant variants of C. jejuni strains or in combination with another phage that binds F336-resistant variants (Sandhu et al., 2021).

Interestingly, Sorensen et al. (2021) indicated that PV Campylobacter-dependent phages can imitate their hosts and avoid bacterial resistance. Sorensen et al. (2021) observed that the Fletchervirus genus from Myovirideae family of Campylobacter phages similar to their host contain hypermutable traits, which influence phase variable expression of some of the receptorbinding proteins. In addition, the resulting phenotypically varied phage populations contain sub-populations that can infect the host when PV-receptor is not present, supporting co-existence of phage and host in the shared environment (Sorensen et al., 2021). Phenotypic variability that can be generated by PV can limit duplicability of results with C. jejuni. Currently, there does not appear to be routine commercial applications for Campylobacter phages, due to Campylobacter phase variation and genomic instability. However, this may be resolved with the latest research from Yamamoto et al. (2021) demonstrating a potential to stabilize the Campylobacter genome in one phase variation state that could be used to devise practical phage applications.

\section{FUTURE STRATEGIES FOR OPTIMIZING PHAGE APPLICATION IN POULTRY PRODUCTION}

Campylobacter phage biocontrol for poultry production appears to have promise. However, several strategies involving current and future developments need to be explored to optimize their efficacy from a practical standpoint. These current and future strategies represent some possible development strategies to improve phage effectiveness and potentially achieve routine commercial application in poultry. One of the considerations for practical phage therapy is developing the appropriate delivery system to apply the bacteriophages. Since phages are selfreplicating, single dosing of Campylobacter phages in birds may be sufficient, though it depends on high bacterial concentrations (Loc Carrillo and Abedon, 2011). When and where to apply Campylobacter phages in poultry processing requires strategic approaches that consider the biology of the bacteriophage and its interaction with target host cells. Capparelli et al. (2010) found an inverse relationship between the incidence of lytic phages and their hosts. Different from what happens with antibiotics, administration of phages when the bacterial count is low may be ineffective. Thus, one phage dose may be appropriate only when the target bacterial population divides rapidly while multiple phage administration doses are employed when bacteria divide slowly (Capparelli et al., 2010). In contrast, Bigwood et al. (2009) observed that a certain threshold of phages was sufficient to decrease the Campylobacter counts without the need of excessive replication. In addition, the reduction of Campylobacter cells was more significant for lower concentrations of host bacterial cells in the liquid culture. Conveniently, because of their low toxicity and resistance to degradation, phages can be supplied within the drinking water or feed to allow for continuous dosing throughout the rearing period (Kittler et al., 2013).

More radical approaches for applying Campylobacter phages in poultry may offer promise to overcome some of the issues encountered with general phage therapy, such as the development of host cell resistance. For example, phage endolysins have a broader host specificity than lytic phages (Siringan et al., 2011). Along these lines, Zampara et al. (2021) suggested the application of phage-derived enzymes instead of lytic phages to overcome some of the problems inherent with intact phages. Endolysins are phage-programmed enzymes that destroy the peptidoglycan layer when externally added leading to osmotic imbalance and cell death (Zampara et al., 2021). Although endolysins have successfully been used in an antibacterial application and can exhibit low development of resistance, their application is currently more suitable toward Gram-positive bacteria, as Gram-negative bacteria contain an outer membrane that inhibits entry of endolysins to the peptidoglycan layer (Gutiérrez and Briers, 2021). Previous studies have successfully utilized fusion of endolysins with binding domains of bacteriocins or polycationic and amphipathic peptides to surmount the outer membrane barrier of Gram-negative bacteria (Lukacik et al., 2012; Yan et al., 2017; Heselpoth et al., 2019). Recently, Zampara et al. (2020) demonstrated successful application of the fusion of phage T5 receptor-binding protein (RBP) and endolysin (Innolysins) against $E$. coli. In their study, the bactericidal activity proved to be dependent on the phage T5 RBP cognate receptor, FhuA.

Based on Zampara et al. (2020) reporting of a successful bactericidal effect of Innolysins against E. coli, they (Zampara et al., 2021) applied the same concept against C. jejuni. Zampara et al. (2021) demonstrated that the H-fiber derived from a C. jejuni integrated elements (CJIEs)-1 like prophage CAMSA2147 functions as a unique RBP. Zampara et al. (2021) designed Innolysins that target $C$. jejuni by fusing the $\mathrm{H}$-fiber and T5 endolysin. Zampara et al. (2021) noted that the application of Innolysins on chicken skin at $5^{\circ} \mathrm{C}$ contaminated with C. jejuni CAMSA2147 led to an average of $1.4 \log _{10}$ reduction of bacteria, indicating that Innolysins can eradicate C. jejuni in situ. Zampara et al. (2021) concluded that the H-fiber potentially recognizes a different receptor on the host cells than the lytic $C$. jejuni phages that bind to the host cell CPS or flagella.

Phage intervention strategy may also be advantageous during the somewhat static steps of poultry processing, where slow Campylobacter growth occurs, such as poultry plant surfaces that may contain biofilms, at the endpoints of processing, and poultry plants that utilize reuse water systems. Phage application can be exceptionally favorable in water reuse systems, which use filters to remove large chemical particles but would allow phages to pass through, offering the potential for a single cocktail to be utilized multiple times as an ongoing component of the recycled water (Mannapperuma and Santos, 2004; Meneses et al., 2017; Micciche et al., 2018). Theoretically, phages can persist in water indefinitely, although inactivation does occur 
(Pinon and Vialette, 2018). Thus, the investigation of phage biocontrol's reuse possibilities within poultry processing water, such as carcass wash waters and chilled water, is warranted. Optimizing Campylobacter phage administration in poultry processing water and reuse water will require determining whether inactivation problems occur and can be overcome. It also would be worth determining whether Campylobacter phage can remain active in the presence of antimicrobials such as acids typically used in poultry processing plants. If phages remain viable and sustain their lytic properties, the potential of introducing phages as a component of multiple hurdle interventions that include non-phage antimicrobials such as acids would be highly attractive.

Bacteriophages may hold other advantages for application in the poultry processing plant. Due to their very low toxicity and specific host range (Loc Carrillo and Abedon, 2011), large quantities of phages could be added to processing waters with little to no risk to workers, which can concern when employing traditional chemical sanitizers. Most lytic phages, including Campylobacter phages, do not produce toxic by-products and have little to no harmful effect on humans or birds (Skurnik et al., 2007; Abedon et al., 2011; Loc Carrillo and Abedon, 2011). However, it has been noted that phages can interact with host immune systems, resulting in a harmful but reversible immune response (Alisky et al., 1998; Kutateladze and Adamia, 2010). In addition, since phages are grown and isolated from cultures containing pathogenic host cell bacteria, improper purification can lead to pathogenic bacterial components triggering severe immune responses (Skurnik and Strauch, 2006; Skurnik et al., 2007). To overcome this, ion-exchange chromatography or highspeed centrifugation can ensure separation between the phage and residual bacterial components (Bogovazova et al., 1992; Sulakvelidze et al., 2001). Regardless, in preharvest environments, appropriate controls will need to be implemented to optimize the application of phages and the immune response. In addition, unlike traditional sanitizers and regardless of concentration, phages have no deleterious impacts regarding food quality (Greer, 1986, 2005; Barrow and Soothill, 1997).

\section{CONCLUSION}

Quantitative risk assessments have concluded that reductions in Campylobacter both pre-and postharvest poultry production would potentially mitigate the health risk posed by campylobacteriosis (Havelaar et al., 2007; Lake et al., 2007; Nauta and Havelaar, 2008; Nauta et al., 2009). While bacteriophages may not eliminate Campylobacter from chicken ceca or carcass, their ability to reduce bacterial counts represents a promising avenue for eliminating the risk of contamination from a finished product. The precise mechanisms of Campylobacter phage lytic activity and host cell resistance must be elucidated to utilize phages for widespread control of Campylobacter. Some of these may be overcome by a targeted selection of Campylobacter phages and phage cocktails that contain multiple Campylobacter families or groups of phages with a wide range of specificities to accommodate host cell variability. Development of non-phage technologies such as isolation of endolysins and fusion with various host cell binding proteins may offer a novel strategy that overcomes Campylobacter host cell resistance in a more general fashion.

Evaluation of phage cocktails should also be investigated to remediate biofilms on processing surfaces. However, biofilm extracellular composition depends on the microbial populations present. Therefore, phages that code for polysaccharide depolymerase may effectively be applied with other phages against biofilms comprised of diverse microbial populations. As such, Campylobacter phage cocktails should be evaluated against biofilms that contain multiple bacterial genera to assess if Campylobacter population reductions are still observed in the presence of these mixed bacterial populations. Ultimately, mixtures of Campylobacter phages and non-Campylobacter phages may need to be employed to overcome biofilms that consist of fairly complex microbial ecosystems. It would be interesting to determine whether synergism for disruption of these more complex biofilms would occur when a multiple mixed phage cocktail is applied.

Campylobacter phage treatment can be implemented in poultry live bird production and processing operations with appropriate safety and quality practices. Nevertheless, understanding how phages acquire resistance and specifically how Campylobacter phages infect their host is essential for optimizing the efficacy under commercial conditions. As Campylobacter phage biology is better understood, optimizing their routine application in poultry production should be achievable. Indeed, better search tools for isolating Campylobacter phage with more broad-spectrum host specificity and optimizing delivery systems for maximum efficacy should offer incremental improvements. However, equally important will be the strategic application of Campylobacter phages within the various phases of poultry production. For example, postharvest employment during poultry processing may result in reducing risk more effectively than elsewhere. However, even within poultry processing, certain stages such as those that involve carcass rinses or reuse water may be more optimal delivery systems. With potential developments in phage technologies and a more strategic application management approach in both pre-and postharvest poultry environments, Campylobacter phages offer a viable potential hurdle for administration at multiple places throughout poultry production.

\section{AUTHOR CONTRIBUTIONS}

EO wrote the latest version of the manuscript. SR helped with writing and editing of the manuscript. AM, YY, and MR contributed to the first draft of the manuscript. All authors listed approved the manuscript for publication.

\section{FUNDING}

AM was supported by a Distinguished Doctoral Fellowship and support from the Department of Food Science at the University of Arkansas. 


\section{REFERENCES}

Abedon, S. (2011). Chapter 1 - Phage therapy pharmacology: calculating phage dosing. Adv. Appl. Microbiol. 77, 1-40. doi: 10.1016/B978-0-12-387044-5. 00001-7

Abedon, S. T., Kuhl, S. J., Blasdel, B. G., and Kutter, E. M. (2011). Phage treatment of human infections. Bacteriophage 1, 66-85. doi: 10.4161/bact.1.2.15845

Ackermann, H. W. (2009). Basic phage electron microscopy. Methods Mol. Biol. 501, 113-126. doi: 10.1007/978-1-60327-164-6_12

Adams, M. (1959). Bacteriophages. New York, NY: Wiley Interscience.

Alisky, J., Iczkowski, K., Rapoport, A., and Troitsky, N. (1998). Bacteriophages show promise as antimicrobial agents. J. Infect. 36, 5-15. doi: 10.1016/s01634453(98)92874-2

Alphen, L. B., Wenzel, C. Q., Richards, M. R., Fodor, C., Ashmus, R. A., Stahl, M., et al. (2014). Biological roles of the O-methyl phosphoramidate capsule modification in Campylobacter jejuni. PLoS One 9:e87051. doi: 10.1371/journal. pone.0087051

An, J. U., Ho, H., Kim, J., Kim, W. H., Kim, J., Lee, S., et al. (2018). Dairy cattle, a potential reservoir of human campylobacteriosis: epidemiological and molecular characterization of Campylobacter jejuni from cattle farms. Front. Microbiol. 9:3136. doi: 10.3389/fmicb.2018.03136

Arnold, J. W., and Silvers, S. (2000). Comparison of poultry processing equipment surfaces for susceptibility to bacterial attachment and biofilm formation. Poult. Sci. 79, 1215-1221. doi: 10.1093/ps/79.8.1215

Atterbury, R. J., Connerton, P. L., Dodd, C. E., Rees, C. E., and Connerton, I. F. (2003b). Isolation and characterization of Campylobacter bacteriophages from retail poultry. Appl. Environ. Microbiol. 69, 4511-4518. doi: 10.1128/aem.69.8.4511-4518. 2003

Atterbury, R. J., Connerton, P. L., Dodd, C. E., Rees, C. E., and Connerton, I. F. (2003a). Application of host-specific bacteriophages to the surface of chicken skin leads to a reduction in recovery of Campylobacter jejuni. Appl. Environ. Microbiol. 69, 6302-6306. doi: 10.1128/AEM.69.10.6302-6306.2003

Atterbury, R. J., Dillon, E., Swift, C., Connerton, P. L., Frost, J. A., Dodd, C. E., et al. (2005). Correlation of Campylobacter bacteriophage with reduced presence of hosts in broiler chicken ceca. Appl. Environ. Microbiol. 71, 4885-4887. doi: 10.1128/AEM.71.8.4885-4887.2005

Barrangou, R., Fremaux, C., Deveau, H., Richards, M., Boyaval, P., Moineau, S., et al. (2007). CRISPR provides acquired resistance against viruses in prokaryotes. Science 315, 1709-1712. doi: 10.1126/science.113 8140

Barrow, P. A. (2001). The use of bacteriophages for treatment and prevention of bacterial disease in animals and animal models of human infection. J. Chem. Technol. Biotechnol. 76, 677-682. doi: 10.1002/jctb.436

Barrow, P. A., and Soothill, S. (1997). Bacteriophage therapy and prophylaxis: rediscovery and renewed assessment of potential. Trends Genet. 5, 268-271. doi: 10.1016/S0966-842X(97)01054-8

Bastías, R., Higuera, G., Sierralta, W., and Espejo, R. T. (2010). A new group of cosmopolitan bacteriophages induce a carrier state in the pandemic strain of Vibrio parahaemolyticus. Environt. Microbiol. 12, 990-1000. doi: 10.1111/j. 1462-2920.2010.02143.x

Berrang, M. E., Buhr, R. J., and Cason, J. A. (2000). Campylobacter recovery from external and internal organs of commercial broiler carcass prior to scalding. Poult. Sci. 79, 286-290. doi: 10.1093/ps/79.2.286

Bigwood, T., Hudson, J. A., and Billington, C. (2009). Influence of host and bacteriophage concentrations on the inactivation of food-borne pathogenic bacteria by two phages. FEMS Microbiol. Lett. 291, 59-64. doi: 10.1111/j.15746968.2008.01435.x

Bigwood, T., Hudson, J. A., Billington, C., Carey-Smith, G. V., and Heinemann, J. A. (2008). Phage inactivation of foodborne pathogens on cooked and raw meat. Food Microbiol. 25, 400-406. doi: 10.1016/j.fm.2007.11.003

Black, R. E., Levine, M. M., Clements, M. L., Hughes, T. P., and Blaser, M. J. (1988). Experimental Campylobacter jejuni infection in humans. J. Infect. Dis. 157, 472-479. doi: 10.1093/infdis/157.3.472

Bogovazova, G. G., Voroshilova, N. N., Bondarenko, V. M., Gorbatkova, G. A., Afanas'eva, E. V., Kazakova, T. B., et al. (1992). Immunobiological properties and therapeutic effectiveness of preparations from Klebsiella bacteriophages. $Z$ h. Mikrobiol. Epidemiol. Immunobiol. 3, 30-33.
Bradde, S., Vucelja, M., Teşileanu, T., and Balasubramanian, V. (2017). Dynamics of adaptive immunity against phage in bacterial populations. PLoS Comput. Biol. 13:e1005486. doi: 10.1371/journal.pcbi.1005486

Brathwaite, K. J., Siringan, P., Moreton, J., Wilson, R., and Connerton, I. F. (2013). Complete genome sequence of universal bacteriophage host strain Campylobacter jejuni subsp. jejuni PT14. Genome Announc. 1:e00969-13. doi: 10.1128/genomeA.00969-13

Brown, C. M., and Bidle, K. D. (2014). Attenuation of virus production at high multiplicities of infection in Aureococcus anophagefferens. Virol. J. 466, 71-81. doi: 10.1016/j.virol.2014.07.023

Brown, H. L., Hanman, K., Reuter, M., Betts, R. P., and van Vliet, A. H. (2015). Campylobacter jejuni biofilms contain extracellular DNA and are sensitive to DNase I treatment. Front. Microbiol. 6:699. doi: 10.3389/fmicb.2015.00699

Brussow, H., Canchaya, C., and Hardt, W. D. (2004). Phages and the evolution of bacterial pathogens: from genomic rearrangements to lysogenic conversion. Microbiol. Mol. Biol. Rev. 68, 560-602. doi: 10.1128/MMBR.68.3.560-602.2004

Burmeister, A. R., Fortier, A., Roush, C., Lessing, A. J., Bender, R. G., Barahman, R., et al. (2020). Pleiotropy complicates a trade-off between phage resistance and antibiotic resistance. Proc. Natl. Acad. Sci. U.S.A. 117, 11207-11216. doi: 10.1073/pnas.1919888117

Cairns, B. J., Timms, A. R., Jansen, V. A., Connerton, I. F., and Payne, R. J. (2009). Quantitative models of in vitro bacteriophage-host dynamics and their application to phage therapy. PLoS Pathog. 5:e1000253. doi: 10.1371/journal. ppat. 1000253

Callaway, T. R., Anderson, R. C., Edrington, T. S., Genovese, K. J., Harvey, R. B., Poole, T. L., et al. (2004). Recent pre-harvest supplementation strategies to reduce carriage and shedding of zoonotic enteric bacterial pathogens in food animals. Anim. Health Res. Rev. 5, 35-47. doi: 10.1079/ahr200462

Capparelli, R., Nocerino, N., Iannaccone, M., Ercolini, D., Parlato, M., Chiara, M., et al. (2010). Bacteriophage therapy of Salmonella enterica: a fresh appraisal of bacteriophage therapy. J. Infect. Dis. 201, 52-61. doi: 10.1086/648478

Carvalho, C. M., Gannon, B. W., Halfhide, D. E., Santos, S. B., Hayes, C. M., Roe, J. M., et al. (2010). The in vivo efficacy of two administration routes of a phage cocktail to reduce numbers of Campylobacter coli and Campylobacter jejuni in chickens. BMC Microbiol. 10:232. doi: 10.1186/1471-2180-10-232

Carvalho, C. M., Santos, S. B., Kropinski, A. M., Ferreira, E. C., and Azeredo, J. (2012). Phages as Therapeutic Tools to Control Major Foodborne Pathogens: Campylobacter and Salmonella, Bacteriophages, Ipek Kurtboke. London: IntechOpen.

Centers for Disease Control and Prevention [CDC] (2019). Campylobacteriosis. Information for Health Professionals. Atlanta: CDC.

Ceri, H., Olson, M. E., Stremick, C., Read, R. R., Morck, D., and Buret, A. (1999). The calgary biofilm device: new technology for rapid determination of antibiotic susceptibilities of bacterial biofilms. J. Clin. Microbiol. 37, 1771-1776. doi: 10.1128/JCM.37.6.1771-1776.1999

Chapman, B., Otten, A., Fazil, A., Ernst, N., and Smith, B. A. (2016). A review of quantitative microbial risk assessment and consumer process models for Campylobacter in broiler chickens. Microb. Risk Anal. 2, 3-15. doi: 10.1016/j. mran.2016.07.001

Chibani-Chennoufi, S., Bruttin, A., Dillmann, M. L., and Brüssow, H. (2004). Phage-host interaction: an ecological perspective. J. Bacteriol. Res. 186, 36773686. doi: 10.1128/JB.186.12.3677-3686.2004

Clark, C. G., Grant, C. C., Pollari, F., Marshall, B., Moses, J., Tracz, D. M., et al. (2012). Effects of the Campylobacter jejuni CJIE1 prophage homologs on adherence and invasion in culture, patient symptoms, and source of infection. BMC Microbiol. 12:269. doi: 10.1186/1471-2180-12-269

Connerton, I. F., Connerton, P. L., Barrow, P., Seal, B. S., and Atterbury, R. J. (2008). "Bacteriophage therapy and Campylobacter," in Campylobacter, 3rd Edn, eds I. Nachamkin, C. M. Szymanski, and M. J. Blaser (Washington, DC: ASM Press), 679-693. doi: 10.1128/9781555815554.ch38

Connerton, P. L., Loc Carrillo, C. M., Swift, C., Dillon, E., Scott, A., Rees, C. E., et al. (2004). Longitudinal study of Campylobacter jejuni bacteriophages and their hosts from broiler chickens. Appl. Environ. Microbiol. 70, 3877-3883. doi: 10.1128/AEM.70.7.3877-3883.2004

Connerton, P. L., Richards, P. J., Lafontaine, G. M., O'Kane, P. M., Ghaffar, N., Cummings, N. J., et al. (2018). The effect of the timing of exposure to Campylobacter jejuni on the gut microbiome and inflammatory responses of broiler chickens. Microbiome 6:88. doi: 10.1186/s40168-018-0477-475 
Connerton, P. L., Timms, A. R., and Connerton, I. F. (2011). Campylobacter bacteriophages and bacteriophage therapy. J. Appl. Microbiol. 111, 255-265. doi: 10.1111/j.1365-2672.2011.05012.x

Coward, C., Grant, A. J., Swift, C., Philp, J., Towler, R., Heydarian, M., et al. (2006). Phase-variable surface structures are required for infection of Campylobacter jejuni by bacteriophages. Appl. Environ. Microbiol. 72, 4638-4647. doi: 10.1128/ AEM.00184-06

Deborde, M., and Von Gunten, U. R. S. (2008). Reactions of chlorine with inorganic and organic compounds during water treatment-kinetics and mechanisms: a critical review. Water Res. 42, 13-51. doi: 10.1016/j.watres.2007.07.025

Deng, W., Dittoe, D. K., Pavilidis, H. O., Chaney, W. E., Yang, Y., and Ricke, S. C. (2020). Current perspectives and potential of probiotics to limit foodborne Campylobacter in poultry. Front. Microbiol. 11:583429. doi: 10.3389/fmicb. 2020.583429

Dufrenne, J., Ritmeester, W., Asch, E. D. V., Van Leusden Frans, A., and De Jonge, R. (2001). Quantification of the contamination of chicken and chicken products in the Netherlands with Salmonella and Campylobacter. J. Food Prot. 64, 538-541. doi: 10.4315/0362-028x-64.4.538

Dugar, G., Herbig, A., Förstner, K. U., Heidrich, N., Reinhardt, R., Nieselt, K., et al. (2013). High-resolution transcriptome maps reveal strain-specific regulatory features of multiple Campylobacter jejuni isolates. PLoS Genet. 9:e1003495. doi: 10.1371/journal.pgen.1003495

El-Shibiny, A., Connerton, P. L., and Connerton, I. F. (2005). Enumeration and diversity of campylobacters and bacteriophages isolated during the rearing cycles of free-range and organic chickens. Appl. Environ. Microbiol. 71, 12591266. doi: 10.1128/aem.71.3.1259-1266.2005

El-Shibiny, A., Scott, A., Timms, A., Metawea, Y., Connerton, P., and Connerton, I. (2009). Application of a group II Campylobacter bacteriophage to reduce strains of Campylobacter jejuni and Campylobacter coli colonizing broiler chickens. J. Food Prot. 72, 733-740. doi: 10.4315/0362-028x-72.4.733

Elvers, K. T., Morris, V. K., Newell, D. G., and Allen, V. M. (2011). Molecular tracking, through processing, of Campylobacter strains colonizing broiler flocks. Appl. Environ. Microbiol. 77, 5722-5729. doi: 10.1128/AEM.02419-2410

European Food Safety Authority [EFSA] (2011). The European Union summary report on trends and sources of zoonoses, Zoonotic agents and food-borne outbreaks in 2009. EFSA J. 9:2090.

European Food Safety Authority [EFSA] (2020). Update and review of control options for Campylobacter in broilers at primary production. EFSA J. 18:6090. doi: $10.2903 /$ j.efsa.2020.6090

Fischer, S., Kittler, S., Klein, G., and Glünder, G. (2013). Impact of a single phage and a phage cocktail application in broilers on reduction of Campylobacter jejuni and development of resistance. PLoS One 8:e78543. doi: 10.1371/journal. pone. 0078543

Flemming, H. C. (2008). Biofilms. The Encyclopedia of Life Sciences. Chichester: John Wiley and Sons.

Fletcher, R. D. (1968). Activity and morphology of Vibrio coli phage. Am. J. Vet. Res. 26, 361-364.

Fletcher, R. D., and Bertschinger, H. U. (1964). A method of isolation of Vibrio coli from swine fecal material by selective filtration. Zentralbl. Veterinärmed. Reihe B 11, 469-474. doi: 10.1111/j.1439-0450.1964.tb01075.x

Frost, J. A., Kramer, J. M., and Gillanders, S. A. (1999). Phage typing of Campylobacter jejuni and Campylobacter coli and its use as an adjunct to serotyping. Epidemiol. Infect. 123, 47-55. doi: 10.1017/s095026889900254x

Gaasbeek, E. J., Wagenaar, J. A., Guilhabert, M. R., van Putten, J. P., Parker, C. T., and van der Wal, F. J. (2010). Nucleases encoded by the integrated elements CJIE2 and CJIE4 inhibit natural transformation of Campylobacter jejuni. J. Bacteriol. 192, 936-941. doi: 10.1128/JB.00867-09

Gaasbeek, E. J., Wagenaar, J. A., Guilhabert, M. R., Wosten, M. M., van Putten, J. P., van der Graaf-van Bloois, L., et al. (2009). A DNase encoded by integrated element CJIE1 inhibits natural transformation of Campylobacter jejuni. J. Bacteriol. 191, 2296-2306. doi: 10.1128/JB.01430-08

García-Sánchez, L., Melero, B., Jaime, I., Hänninen, M.-L., Rossi, M., and Rovira, J. (2017). Campylobacter jejuni survival in a poultry processing plant environment. Food Microbiol. 65, 185-192. doi: 10.1016/j.fm.2017. 02.009

Gencay, Y. E., Birk, T., Sørensen, M. C. H., and Brøndsted, L. (2017). "Methods for isolation, purification, and propagation of bacteriophages of Campylobacter jejuni," in Campylobacter jejuni Methods in Molecular Biology, Vol. 1512, eds
J. Butcher and A. Stintzi (New York, NY: Humana Press). doi: 10.1007/978-14939-6536-6_3

Gencay, Y. E., Sørensen, M. C., Wenzel, C. Q., Szymanski, C. M., and Brøndsted, L. (2018). Phase variable expression of a single phage receptor in Campylobacter jejuni NCTC12662 influences sensitivity toward several diverse CPS-dependent phages. Front. Microbiol. 9:82. doi: 10.3389/fmicb.2018.00082

Gilbert, S. E., Whyte, R., Bayne, G., Paulin, S. M., Lake, R. J., and van der Logt, P. (2007). Survey of domestic food handling practices in New Zealand. Int. J. Food Microbiol. 117, 306-311. doi: 10.1016/j.ijfoodmicro.2007.05.004

Goode, D., Allen, V. M., and Barrow, P. A. (2003). Reduction of experimental Salmonella and Campylobacter contamination of chicken skin by application of lytic bacteriophages. Appl. Environ. Microbiol. 69, 5032-5036. doi: 10.1128/ AEM.69.8.5032-5036.2003

Goodridge, L. D., and Bisha, B. (2011). Phage-based biocontrol strategies to reduce foodborne pathogens in foods. Bacteriophage 1, 130-137. doi: 10.4161/bact.1.3. 17629

Grajewski, B. A., Kusek, J. W., and Gelfand, H. M. (1985). Development of a bacteriophage typing system for Campylobacter jejuni and Campylobacter coli. J. Clin. Microbiol. 22, 13-18. doi: 10.1128/jcm.22.1.13-18.1985

Green, M. R., and Sambrook, J. (2012). Molecular Cloning: A Laboratory Manual, Fourth Edn. Cold Spring Harbor, NY: Cold Spring Harbor Laboratory Press.

Greer, G. G. (1986). Homologous bacteriophage control of Pseudomonas growth and beef spoilage. J. Food Prot. 49, 104-109. doi: 10.4315/0362-028x-49.2.104

Greer, G. G. (2005). Bacteriophage control of foodborne bacteria. J. Food Prot. 68, 1102-1111. doi: 10.4315/0362-028x-68.5.1102

Grissa, I., Vergnaud, G., and Pourcel, C. (2007). CRISPRFinder: a web tool to identify clustered regularly interspaced short palindromic repeats. Nucleic Acids Res. 35, W52-W57. doi: 10.1093/nar/gkm360

Gunther, N. W., and Chen, C. Y. (2009). The biofilm forming potential of bacterial species in the genus Campylobacter. Food Microbiol. 26, 44-51. doi: 10.1016/j. fm.2008.07.012

Gutiérrez, D., and Briers, Y. (2021). Lysins breaking down the walls of Gram negative bacteria, no longer a no-go. Curr. Opin. Biotechnol. 68, 15-22. doi: 10.1016/j.copbio.2020.08.014

Hald, B., Rattenborg, E., and Madsen, M. (2001). Role of batch depletion of broiler houses on the occurrence of Campylobacter spp. in chicken flocks. Lett. Appl. Microbiol. 32, 253-256. doi: 10.1046/j.1472-765x.2001.00896.x

Hammerl, J. A., Jäckel, C., Alter, T., Janzcyk, P., Stingl, K., Knüver, M. T., et al. (2014). Reduction of Campylobacter jejuni in broiler chicken by successive application of group II and group III phages. PLoS One 9:e114785. doi: 10.1371/ journal.pone.0114785

Hammerl, J. A., Jäckel, C., Reetz, J., Beck, S., Alter, T., Lurz, R., et al. (2011). Campylobacter jejuni group III phage CP81 contains many T4-like genes without belonging to the T4-type phage group: implications for the evolution of T4 phages. J. Virol. 85, 8597-8605. doi: 10.1128/JVI.00395-11

Hanning, I., Biswas, D., Herrera, P., Roesler, M., and Ricke, S. C. (2010). Prevalence and characterization of Campylobacter jejuni isolated from pasture flock poultry. J. Food Sci. 75, M496-M502. doi: 10.1111/j.1750-3841.2010.01747.x

Hansen, V. M., Rosenquist, H., Baggesen, D. L., Brown, S., and Christensen, B. B. (2007). Characterization of Campylobacter phages including analysis of host range by selected Campylobacter Penner serotypes. BMC Microbiol. 7:90. doi: 10.1186/1471-2180-7-90

Harada, L. K., Silva, E. C., Campos, W. F., Del Fiol, F. S., Vila, M., Dabrowska, K., et al. (2018). Biotechnological applications of bacteriophages: state of the art. Microbiol. Res. 212-213, 38-58. doi: 10.1016/j.micres.2018.04.007

Harper, D. R., Parracho, H. M. R. T., Walker, J., Sharp, R., Hughes, G., Werthen, M., et al. (2014). Bacteriophages and biofilms. Antibiotics 3, 270-284. doi: 10.3390/antibiotics3030270

Havelaar, A. H., Haagsma, J. A., Mangen, M. J., Kemmeren, J. M., Verhoef, L. P., and Vijgen, S. M. (2012). Disease burden of foodborne pathogens in the Netherlands. Int. J. Food Microbiol. 156, 231-238. doi: 10.1016/j.ijfoodmicro. 2012.03.029

Havelaar, A. H., Mangen, M. J. J., De Koeijer, A. A., Bogaardt, M.-J., Evers, E. G., Jacobs- Reitsma, W. F., et al. (2007). Effectiveness and efficiency of controlling Campylobacter on broiler chicken meat. Risk Anal. 27, 831-844. doi: 10.1111/j. 1539-6924.2007.00926.x

Hermans, D., Van Deun, K., Messens, W., Martel, A., Van Immerseel, F., Haesebrouck, F., et al. (2011). Campylobacter control in poultry by current 
intervention measures ineffective: urgent need for intensified fundamental research. Vet. Microbiol. 152, 219-228. doi: 10.1016/j.vetmic.2011.03.010

Heselpoth, R. D., Euler, C. W., and Schuch, R. (2019). Lysocins: bioengineered antimicrobials that deliver lysins across the outer membrane of Gram-negative bacteria. Antimicrob. Agents Chemother. 63:e0342-19. doi: 10.1128/aac.00 $342-19$

Hooton, S., and Connerton, I. F. (2015). Campylobacter jejuni acquire new hostderived CRISPR spacers when in association with bacteriophages harboring a CRISPR-like Cas4 protein. Front. Microbiol. 5:744. doi: 10.3389/fmicb.2014. 00744

Hooton, S., D’Angelantonio, D., Hu, Y., Connerton, P. L., Aprea, G., and Connerton, I. F. (2020). Campylobacter bacteriophage DA10: an excised temperate bacteriophage targeted by CRISPR-cas. BMC Genomics 21:400. doi: 10.1186/s12864-020-06808-3

Huang, H. H., Hoang, M. D., Masuda, Y., Honjoh, K., and Miyamoto, T. (2020). Characterization and utilization of phages specific to Campylobacter coli. Access Microbiol. 2:18. doi: 10.1099/acmi.fis2019.po0112

Hughes, K. A., Sutherland, I. W., and Jones, M. V. (1998). Biofilm susceptibility to bacteriophage attack: the role of phage-borne polysaccharide depolymerase. Microbiology 144, 3039-3047. doi: 10.1099/00221287-144-11-3039

Humphrey, T. J., Henley, A., and Lanning, D. G. (1993). The colonization of broiler chickens with Campylobacter jejuni: some epidemiological investigations. Epidemiol. Infect. 110, 601-607. doi: 10.1017/s0950268800051025

Humphrey, T. J., and Lanning, D. G. (1987). Salmonella and Campylobacter contamination of broiler chicken carcasses and scald tank water: the influence of water pH. J. Appl. Bacteriol. 63, 21-25. doi: 10.1111/j.1365-2672.1987. tb02413.x

Hwang, S., Yun, J., Kim, K. P., Heu, S., Lee, S., and Ryu, S. (2009). Isolation and characterization of bacteriophages specific for Campylobacter jejuni. Microbiol. Immun. 53, 559-566. doi: 10.1111/j.1348-0421.2009.00163.x

Indikova, I., Humphrey, T. J., and Hilbert, F. (2015). Survival with a helping hand: Campylobacter and microbiota. Front. Microbiol. 6:1266. doi: 10.3389/fmicb. 2015.01266

Ishino, Y., Shinagawa, H., Makino, K., Amemura, M., and Nakata, A. (1987). Nucleotide sequence of the iap gene, responsible for alkaline phosphatase isozyme conversion in Escherichia coli, and identification of the gene product. J. Bacteriol. 169, 5429-5433. doi: 10.1128/jb.169.12.5429-5433. 1987

Jäckel, C., Hammerl, J. A., and Hertwig, S. (2019). Campylobacter phage isolation and characterization: what we have learned so far. Methods Protoc. 2:18. doi: $10.3390 / \mathrm{mps} 2010018$

Jäckel, C., Hammerl, J. A., Rau, J., and Hertwig, S. (2017). A multiplex real-time PCR for the detection and differentiation of Campylobacter phages. PLoS One 12:e0190240. doi: 10.1371/journal.pone.0190240

Jäckel, C., Hammerl, J. A., Reetz, J., Kropinski, A. M., and Hertwig, S. (2015). Campylobacter group II phage CP21 is the prototype of a new subgroup revealing a distinct modular genome organization and host specificity. BMC Genom. 16:629. doi: 10.1186/s12864-015-1837-1

Janež, N., Kokošin, A., Zaletel, E., Vranac, T., Kovač, J., Vučković, D., et al. (2014). Identification and characterisation of new Campylobacter group III phages of animal origin. FEMS Microbiol. Lett. 359, 64-71. doi: 10.1111/1574-6968.12556

Janez, N., and Loc-Carillo, C. (2013). Use of phages to control Campylobacter spp. J. Microbiol. Method 95, 68-75. doi: 10.1016/j.mimet.2013.06.024

Jarling, M., Bartkowiak, K., Robenek, H., Pape, H., and Meinhardt, F. (2004). Isolation of phages infecting Actinoplanes SN223 and characterization of two of these viruses. Appl. Microbiol. Biotechnol. 64, 250-254. doi: 10.1007/s00253003-1473-6

Jauk, V., Neubauer, C., Szölgyényi, W., and Vasicek, L. (2003). Phenotypic and genotypic differentiation of Campylobacter spp. isolated from Austrian broiler farms: a comparison. Avian Pathol. 32, 33-37. doi: 10.1080/ 0307945021000070697

Javed, M. A., Ackermann, H. W., Azeredo, J., Carvalho, C. M., Connerton, I., Evoy, S., et al. (2014). A suggested classification for two groups of Campylobacter myoviruses. Arch. Virol. 159, 181-190. doi: 10.1007/s00705-013$1788-2$

Jiang, F., and Doudna, J. A. (2017). CRISPR-Cas9 structures and mechanisms. Annu. Rev. Biophys. 46, 505-529. doi: 10.1146/annurev-biophys-062215010822
Jones, L. M., Mcduff, C. R., and Wilson, J. B. (1962). Phenotypic alterations in the colonial morphology of Brucella abortus due to a bacteriophage carrier state. J. Bacteriol. 83, 860-866. doi: 10.1128/jb.83.4.860-866.1962

Kasman, L. M., Kasman, A., Westwater, C., Dolan, J., Schmidt, M. G., and Norris, J. S. (2002). Overcoming the phage replication threshold: a mathematical model with implications for phage therapy. J. Virol. 76, 5557-5564. doi: 10.1128/jvi.76. $11.5557-5564.2002$

Kiljunen, S., Hakala, K., Pinta, E., Huttunen, S., Pluta, P., Gador, A., et al. (2005). Yersiniophage phiR1-37 is a tailed bacteriophage having a $270 \mathrm{~kb}$ DNA genome with thymidine replaced by deoxyuridine. Microbiology 151, 4093-4102. doi: $10.1099 /$ mic. $0.28265-0$

Kim, S. A., Jang, M. J., Kim, S. Y., Yang, Y., Pavlidis, H. O., and Ricke, S. C. (2019). Potential for prebiotics as feed additives to limit foodborne Campylobacter establishment in the poultry gastrointestinal tract. Front. Microbiol. 10:91. doi: 10.3389/fmicb.2019.00091

Kittler, S., Fischer, S., Abdulmawjood, A., Glünder, G., and Klein, G. (2013). Effect of bacteriophage application on Campylobacter jejuni loads in commercial broiler flocks. Appl. Environ. Microbiol. 79, 7525-7533. doi: 10.1128/AEM. 02703-13

Korczak, B. M., Stieber, R., Emler, S., Burnens, A. P., Frey, J., and Kuhnert, P. (2006). Genetic relatedness within the genus Campylobacter inferred from $r p o B$ sequences. Int. J. Syst. Evol. Microbiol. 56, 937-945. doi: 10.1099/ijs.0.6410964100

Kutateladze, M., and Adamia, R. (2010). Bacteriophages as potential new therapeutics to replace or supplement antibiotics. Trends Biotechnol. 28, 591595. doi: 10.1016/j.tibtech.2010.08.001

Labrie, S. J., Samson, J. E., and Moineau, S. (2010). Bacteriophage resistance mechanisms. Nat. Rev. Microbiol. 8:317. doi: 10.1038/nrmicro2315

Lake, R., Hudson, A., Cressey, P., and Bayne, G. (2007). Quantitative Risk Model: Campylobacter spp. in the Poultry Food Chain. Christchurch: Institute of Environmental Science and Research Limited, 1-91.

Levin, B. R., and Bull, J. J. (2004). Population and evolutionary dynamics of phage therapy. Nat. Rev. Microbiol. 2, 166-173. doi: 10.1038/nrmicro822

Li, K., Barksdale, L., and Garmise, L. (1961). Phenotypic alterations associated with the bacteriophage carrier state of Shigella dysenteriae. J. Gen. Microbiol. 24, 355-367. doi: 10.1099/00221287-24-3-355

Lis, L., and Connerton, I. F. (2016). The minor flagellin of Campylobacter jejuni (FlaB) confers defensive properties against bacteriophage infection. Front. Microbiol. 7:1908. doi: 10.3389/fmicb.2016.01908

Loc Carrillo, C., and Abedon, S. T. (2011). Pros and cons of phage therapy. Bacteriophage 1, 111-114. doi: 10.4161/bact.1.2.14590

Loc Carrillo, C. L., Atterbury, R. J., El-Shibiny, A., Connerton, P. L., Dillon, E., Scott, A., et al. (2005). Bacteriophage therapy to reduce Campylobacter jejuni colonization of broiler chickens. Appl. Environ. Microbiol. 71, 6554-6563. doi: 10.1128/AEM.71.11.6554-6563.2005

Loc Carrillo, C. M., Connerton, P. L., Pearson, T., and Connerton, I. F. (2007). Free-range layer chickens as a source of Campylobacter bacteriophage. Antonie Van Leeuwenhoek 92, 275-284. doi: 10.1007/s10482-007-9156-9154

Lu, T. K., and Collins, J. J. (2007). Dispersing biofilms with engineered enzymatic bacteriophage. Proc. NatL. Acad. Sci. U.S.A. 104, 11197-11202. doi: 10.1073/ pnas. 0704624104

Lukacik, P., Barnard, T. J., Keller, P. W., Chaturvedi, K. S., Seddiki, N., Fairman, J. W., et al. (2012). Structural engineering of a phage lysin that targets Gram negative pathogens. Proc. Natl. Acad. Sci. U.S.A. 109, 9857-9862. doi: 10.1073/ pnas. 1203472109

Lwoff, A. (1953). Lysogeny. Bacteriol. Rev. 17, 269-337.

Mannapperuma, J. D., and Santos, M. R. (2004). Reconditioning of poultry chiller overflow by ultrafiltration. J. Food Process Eng. 27, 497-516. doi: 10.1111/j.17454530.2004.00474.x

McNally, D. J., Lamoureux, M. P., Karlyshev, A. V., Fiori, L. M., Li, J., Thacker, G., et al. (2007). Commonality and biosynthesis of the O-methyl phosphoramidate capsule modification in Campylobacter jejuni. J. Biol. Chem. 282, 28566-28576. doi: $10.1074 /$ jbc.M704413200

Meneses, Y. E., Stratton, J., and Flores, R. A. (2017). Water reconditioning and reuse in the food processing industry: current situation and challenges. Trends Food Sci. Technol. 61, 72-79. doi: 10.1016/j.tifs.2016.12.008

Micciche, A. C., Rubinelli, P. M., and Ricke, S. C. (2018). Source of water and potential sanitizers and biological antimicrobials for alternative poultry 
processing food safety applications. Front. Sustain. Food Syst. 2:82. doi: 10.3389/ fsufs.2018.00082

Mills, S. D., Kuzniar, B., Shames, B., Kurjanczyk, L. A., and Penner, J. L. (1992). Variation of the $\mathrm{O}$ antigen of Campylobacetr jejuni in vivo. J. Med. Microbiol. 36, 215-219. doi: 10.1099/00222615-36-3-215

Nauta, M., Hill, A., Rosenquist, H., Brynestad, S., Fetsch, A., van der Logt, P., et al. (2009). A comparison of risk assessments on Campylobacter in broiler meat. Int. J. Food Microbiol. 129, 107-123. doi: 10.1016/j.ijfoodmicro.2008.12.001

Nauta, M. J., and Havelaar, A. H. (2008). Risk-based standards for Campylobacter in the broiler meat chain. Food Control. 19, 372-381. doi: 10.1016/j.foodcont. 2007.04.016

Owens, J., Barton, M. D., and Heuzenroeder, M. W. (2013). The isolation and characterization of Campylobacter jejuni bacteriophages from free range and indoor poultry. Vet. Microbiol. 162, 144-150. doi: 10.1016/j.vetmic.2012.08.017

Parker, C. T., Quinones, B., Miller, W. G., Horn, S. T., and Mandrell, R. E. (2006). Comparative genomic analysis of Campylobacter jejuni strains reveals diversity due to genomic elements similar to those present in C. jejuni strain RM1221. J. Clin. Microbiol. 44, 4125-4135. doi: 10.1128/JCM.01231-06

Parkhill, J., Wren, B., Mungall, K., Ketley, J., Churcher, C., Basham, D., et al. (2000). The genome sequence of the food-borne pathogen Campylobacter jejuni reveals hypervariable sequences. Nature 403:665. doi: 10.1038/35001088

Petty, N. K., Foulds, I. J., Pradel, E., Ewbank, J. J., and Salmobnd, G. P. C. (2007). A generalized transducing phage for the murine pathogen Citrobacter rodentium. Microbiology 153, 2984-2988. doi: 10.1099/mic.0.2007/008888-0

Pinon, A., and Vialette, M. (2018). Survival of viruses in water. Intervirology 61, 214-222. doi: 10.1159/000484899

Rabinovitch, A., Aviram, I., and Zaritsky, A. (2003). Bacterial debris - an ecological mechanism for coexistence of bacteria and their viruses. J. Theor. Biol. 224, 377-383. doi: 10.1016/s0022-5193(03)00174-177

Rakhuba, D. V., Kolomiets, E. I., Szwajcer Dey, E., and Novik, G. I. (2010). Bacteriophage receptors, mechanisms of phage adsorption and penetration into host cell. Pol. J. Microbiol. 59, 145-155. doi: 10.33073/pjm-2010-023

Rath, D., Amlinger, L., Rath, A., and Lundgren, M. (2015). The CRISPR-Cas immune system: biology, mechanisms and applications. Biochimie 117, 119128. doi: 10.1016/j.biochi.2015.03.025

Richards, P. J., Connerton, P. L., and Connerton, I. F. (2019). Phage biocontrol of Campylobacter jejuni in chickens does not produce collateral effects on the gut microbiota. Front. Microbiol. 10:476. doi: 10.3389/fmicb.2019.00476

Rizzo, H., Gregory, L., Beraldi, F., Carvalho, A. F., and Pinheiro, E. S. (2015). Campylobacter isolation from the feces of sheep with a history of reproductive disorders bred in the state of Sao Paulo, Brazil. Semina Ciências Agrárias 36, 4207-4214. doi: 10.5433/1679-0359.2015v36n6Supl2p4207

Roach, D. R., and Debarbieux, L. (2017). Phage therapy: awakening a sleeping giant. Emerg. Top. Life Sci. 1, 93-103. doi: 10.1042/ETLS20170002

Rosenquist, H., Nielsen, N. L., Sommer, H. M., Norrung, B., and Christensen, B. B. (2003). Quantitative risk assessment of human Campylobacteriosis associated with thermophilic Campylobacter species in chickens. Int. J. Food Microbiol. 83, 87-103. doi: 10.1016/s0168-1605(02)00317-313

Rudi, K., Hoidal, H. K., Katla, T., Johansen, B. K., Nordal, J., and Jakobsen, K. S. (2004). Direct real-time PCR quantification of Campylobacter jejuni in chicken fecal and cecal samples by integrated cell concentration and DNA purification. Appl. Environ. Microbiol. 70, 790-797. doi: 10.1128/aem.70.2.790-797. 2004

Sails, A. D., Wareing, D. R. A., Bolton, F. J., Fox, A. J., and Curry, A. (1998). Characterisation of 16 Campylobacter jejuni and C. coli typing bacteriophages. J. Med. Microbiol. 47, 123-128. doi: 10.1099/00222615-47-2-123

Salama, S., Bolton, F. J., and Hutchinson, D. N. (1989). Improved method for the isolation of Campylobacter jejuni and Campylobacter coli bacteriophages. Lett. Appl. Microbiol. 8, 5-7. doi: 10.1111/j.1472-765x.1989.tb0 0211.x

Sambrook, J., and Russell, D. W. (2001). Molecular Cloning: A Laboratory Manual, 3rd Edn, Vol. 1. New York, NY: Cold Spring Harbor Laboratory Press.

Sandhu, S. K., Bayliss, C. D., and Morozov, A. Y. (2021). How does feedback from phage infections influence evolution of phase variation in Campylobacter? PLoS Comput. Biol. 17:e1009067. doi: 10.1371/journal.pcbi.100 9067

Scherer, K., Bartelt, E., Sommerfeld, C., and Hildebrandt, G. (2006). Comparison of different sampling techniques and enumeration methods for the isolation and quantification of Campylobacter spp. in raw retail chicken legs. Int. J. Food Microbiol. 108, 115-119. doi: 10.1016/j.ijfoodmicro.2005.08.031

Scott, A. E., Timms, A. R., Connerton, P. L., El-Shibiny, A., and Connerton, I. F. (2007a). Bacteriophage influence Campylobacter jejuni types populating broiler chickens. Environ. Microbiol. 9, 2341-2353. doi: 10.1111/j.1462-2920. 2007.01351.x

Scott, A. E., Timms, A. R., Connerton, P. L., Loc Carrillo, C., Radzum, K. A., and Connerton, I. F. (2007b). Genome dynamics of Campylobacter jejuni in response to bacteriophage predation. PLoS Pathog. 3:119. doi: 10.1371/journal. ppat.0030119

Shah, S. A., Erdmann, S., Mojica, F. J., and Garrett, R. A. (2013). Protospacer recognition motifs: mixed identities and functional diversity. RNA Biol. 10, 891-899. doi: 10.4161/rna.23764

Sharma, M., Ryu, J. H., and Beuchat, L. R. (2005). Inactivation of Escherichia coli O157:H7 in biofilm on stainless steel by treatment with an alkaline cleaner and a bacteriophage. J. Appl. Microbiol. 99, 449-459. doi: 10.1111/j.1365-2672.2005. 02659.x

Sharp, R. (2001). Bacteriophages: biology, history. J. Chem. Technol. Biotechnol. 76, $667-672$.

Sheppard, S. K., and Maiden, M. C. (2015). The evolution of Campylobacter jejuni and Campylobacter coli. Cold Spring Harb. Perspect. Biol. 7:a018119. doi: 10. 1101/cshperspect.a018119

Sillankorva, S., Neubauer, P., and Azaredo, J. (2011). Use of Bacteriophages to Control Biofilms. Saarbrücken: LAP Lambert Academic Publishing.

Siringan, P., Connerton, P. L., Cummings, N. J., and Connerton, I. F. (2014). Alternative bacteriophage life cycles: the carrier state of Campylobacter jejuni. Open Biol. 4:130200. doi: 10.1098/rsob.130200

Siringan, P., Connerton, P. L., Payne, R. J., and Connerton, I. F. (2011). Bacteriophage mediated dispersal of Campylobacter jejuni biofilms. Appl. Environ. Microbiol. 77, 3320-3326. doi: 10.1128/AEM.02704-10

Skarp, C. P. A., Akinrinade, O., Kaden, R., Johansson, C., and Rautelin, H. (2017). Accessory genetic content in Campylobacter jejuni ST21CC isolates from feces and blood. Int. J. Med. Microbiol. 307, 233-240. doi: 10.1016/j.ijmm.2017.04.001

Skurnik, M., Pajunen, M., and Kiljunen, S. (2007). Biotechnological challenges of phage therapy. Biotechnol. Lett. 29, 995-1003. doi: 10.1007/s10529-007-9346-1

Skurnik, M., and Strauch, E. (2006). Phage therapy: facts and fiction. Int. J. Med. Microbiol. 296, 5-14. doi: 10.1016/j.ijmm.2005.09.002

Sorensen, M. C., Gencay, Y. E., and Brondsted, L. (2017). Methods for initial characterization of Campylobacter jejuni bacteriophages. Methods Mol. Biol. 1512, 91-105. doi: 10.1007/978-1-4939-6536-6_9

Sørensen, M. C. H., Gencay, Y. E., Birk, T., Baldvinsson, S. B., Jäckel, C., Hammerl, J. A., et al. (2015). Primary isolation strain determines both phage type and receptors recognised by Campylobacter jejuni bacteriophages. PLoS One 10:e0116287. doi: 10.1371/journal.pone.0116287

Sørensen, M. C. H., Van Alphen, L. B., Frodor, C., Crowley, S., Christensen, B. B., Szymanski, C. M., et al. (2012). Phase variable expression of capsular polysaccharide modifications allows Campylobacter jejuni to avoid bacteriophage infection in chickens. Front. Cell. Infect. Microbiol. 2:11. doi: 10.3389/fcimb.2012.00011

Sørensen, M. C. H., van Alphen, L. B., Harboe, A., Li, J., Christensen, B. B., Szymanski, C. M., et al. (2011). The F336 bacteriophage recognizes the capsular phosphoramidate modification of Campylobacter jejuni NCTC11168. J. Bacteriol. 193, 6742-6749. doi: 10.1128/JB.05276-11

Sorensen, M. C. H., Vitt, A., Neve, H., Soverini, M., Ahern, S. J., Klumpp, J., et al. (2021). Campylobacter phages use hypermutabkle polyG tracts to create phenotypic diversity and evade bacterial resistance. Cell Rep. 35:109214. doi: 10.1016/j.celrep.2021.109214

Stenutz, R., Weintraub, A., and Widmalm, G. (2006). The structures of Escherichia coli O-polysaccharide antigens. FEMS Microbiol. Rev. 30, 382-403.

Sulakvelidze, A., Alavidze, Z., and Morris, J. G. (2001). Bacteriophage therapy. Antimicrob. Agents and Chemother. 45, 649-659. doi: 10.1128/AAC.45.3.649659.2001

Torsvik, T., and Dundas, I. D. (1980). Persisting phage infection in Halobacterium salinarium str. 1. J. Gen. Virol. 47, 29-36. doi: 10.1099/0022-1317-47-1-29

Totten, P. A., Patton, C. M., Tenover, F. C., Barrett, T. J., Stamm, W. E., Steigerwalt, A. G., et al. (1987). Prevalence and characterization of hippurate-negative Campylobacter jejuni in King County, Washington. J. Clin. Microbiol. 25, 1747-1752. 
Tsuei, A. C., Carey-Smith, G. V., Hudson, J. A., Billington, C., and Heinemann, J. A. (2007). Prevalence and numbers of coliphages and Campylobacter jejuni bacteriophages in New Zealand foods. Int. J. Food Microbiol. 116, 121-125. doi: 10.1016/j.ijfoodmicro.2006.12.028

Umaraw, P., Prajapati, A., Verma, A. K., Pathak, V., and Singh, V. P. (2017). Control of Campylobacter in poultry industry from farm to poultry processing unit: a review. Crit. Rev. Food Sci. Nutr. 57, 659-665. doi: 10.1080/10408398. 2014.935847

Ushanov, L., Lasareishvili, B., Janashia, I., and Zautner, A. E. (2020). Application of Campylobacter jejuni phages: challenges and perspectives. Animals 10:279. doi: 10.3390/ani10020279

Van der Veen, S., and Abee, T. (2011). Mixed species biofilms of Listeria monocytogenes and Lactobacillus plantarum show enhanced resistance to benzalkonium chloride and peracetic acid. Int. J. Food Microbiol. 144, 421-431. doi: 10.1016/j.ijfoodmicro.2010.10.029

Vose, D. (2008). Risk Analysis: A Quantitative Guide, Third ed. West Sussex: John Wiley \& Sons Ltd.

Wagenaar, J. A., Van Bergen, M. A., Mueller, M. A., Wassenaar, T. M., and Carlton, R. M. (2005). Phage therapy reduces Campylobacter jejuni colonization in broilers. Vet. Microbiol. 109, 275-283. doi: 10.1016/j.vetmic.2005.06.002

Weinbauer, M. G. (2004). Ecology of prokaryotic viruses. FEMS Microbiol. Rev. 28, 127-181. doi: 10.1016/j.femsre.2003.08.001

Wheeler, T. L., Kalchayanand, N., and Bosilevac, J. M. (2014). Pre-and post-harvest interventions to reduce pathogen contamination in the US beef industry. Meat Sci. 98, 372-382. doi: 10.1016/j.meatsci.2014.06.026

Whyte, P., Collins, J. D., McGill, K., Monahan, C., and O'Mahony, H. (2001). Quantitative investigation of the effects of chemical decontamination procedures on the microbiological status of broiler carcasses during processing. J. Food Protect. 64, 179-183. doi: 10.4315/0362-028x-64.2.179

World Health Organization [WHO] (2018). Campylobacter. Geneva: WHO.

Xiong, X., Wu, G., Wei, Y., Liu, L., Zhang, Y., Su, R., et al. (2020). SspABCD$\mathrm{SspE}$ is a phosphorothioation-sensing bacterial defence system with broad anti-phage activities. Nat. Microbiol. 5, 917-928. doi: 10.1038/s41564-0200700-6

Yamamoto, S., Iyoda, S., and Ohnishi, M. (2021). Stabilizing genetically unstable simple sequence repeats in the Campylobacter jejuni genome by multiplex genome editing: a reliable approach for delineating multiple phase-variable genes. bioRxiv [Preprint]. doi: 10.1101/2021.05.14.444138

Yan, G., Liu, J., Ma, Q., Zhu, R., Guo, Z., Gao, C., et al. (2017). The N-terminal and central domain of colicin A enables phage lysin to lyse Escherichia coli extracellularly. Antonie Van Leeuwenhoek 110, 1627-1635. doi: 10.1007/ s10482-017-0912-9

Zampara, A., Sorensen, M. C. H., Elsser-Gravesn, A., and Brondsted, L. (2017). Significance of phage-host interactions for biocontrol of Campylobacter jejuni in food. Food Control 73(Part B), 1169-1175. doi: 10.1016/j.foodcont.2016.10. 033

Zampara, A., Sorensen, M. C. H., Gencay, Y. E., Grimon, D., Kristiansen, S. H., Jorgenses, L. S., et al. (2021). Developing innolysins against Campylobacter jejuni using a novel prophage receptor-binding protein. Front. Microbiol. 12:619028. doi: 10.3389/fmicb.2021.61 9028

Zampara, A., Sørensen, M. C. H., Grimon, D., Antenucci, F., Vitt, A. R., Bortolaia, V., et al. (2020). Exploiting phage receptor binding proteins to enable endolysins to kill Gram-negative bacteria. Sci. Rep. 10:12087. doi: 10.1038/s41598-02068983-3

Conflict of Interest: The authors declare that the research was conducted in the absence of any commercial or financial relationships that could be construed as a potential conflict of interest.

Publisher's Note: All claims expressed in this article are solely those of the authors and do not necessarily represent those of their affiliated organizations, or those of the publisher, the editors and the reviewers. Any product that may be evaluated in this article, or claim that may be made by its manufacturer, is not guaranteed or endorsed by the publisher.

Copyright (C) 2022 Olson, Micciche, Rothrock, Yang and Ricke. This is an open-access article distributed under the terms of the Creative Commons Attribution License (CC BY). The use, distribution or reproduction in other forums is permitted, provided the original author(s) and the copyright owner(s) are credited and that the original publication in this journal is cited, in accordance with accepted academic practice. No use, distribution or reproduction is permitted which does not comply with these terms. 